\title{
Determination of the copper isotope composition of seawater revisited: A case study from the Mediterranean Sea
}

\author{
Baconnais Isabelle ${ }^{1,2,{ }^{*}}$, Rouxel Olivier ${ }^{2,3}$, Dulaquais Gabriel ${ }^{4}$, Boye Marie ${ }^{4,5}$
}

${ }^{1}$ University of Saskatchewan, Saskatoon, Canada

${ }^{2}$ IFREMER, Centre de Brest, Technopôle Brest Iroise, Plouzané, France

${ }^{3}$ Department of Oceanography, University of Hawaii, Honolulu, USA

${ }^{4}$ Laboratoire des sciences de l'environnement marin, UMR CNRS 6539, Institut Universitaire Européen de la Mer, Université de Bretagne Occidentale, Plouzané, France

${ }^{5}$ Laboratoire d'océanographie et du climat expérimentation et approches numériques, UMR CNRS

7159, Université Pierre et Marie Curie -, Paris, France

* Corresponding author : Isabelle Baconnais, email address : isabelle.baconnais@usask.ca

\begin{abstract}
:
A new technique for the determination of dissolved copper isotope composition $(\delta 65 \mathrm{Cu})$ of seawater was applied to examine copper sources and internal cycling in the Mediterranean Sea. A succession of chelating resin with nitrilotriacetic acid functional groups and strong base anion exchange resin, together with optimization of the multi-collector inductively coupled plasma mass spectrometry set-up allowed to isolate copper from seawater matrix and to measure the $65 \mathrm{Cu} / 63 \mathrm{Cu}$ ratios in seawater with an external precision of $0.06 \%$ ( $2 \mathrm{s.d}$.). This method was first applied for inter-comparison measurements to surface and deep waters sampled at station BATS in the North Atlantic Ocean. Disparities in $\delta 65 \mathrm{Cu}$ reported here and in the literature over these samples showed a need to investigate whether a new inter-comparison sample should be decided upon, or whether the use of UVoxidation can also affect the measurement of $\delta 65 \mathrm{Cu}$. We also measured total dissolved $\mathrm{Cu}$ concentration $([\mathrm{dCu}] \mathrm{T})$ and $\delta 65 \mathrm{Cu}$ for 12 stations in the Mediterranean Sea. The $865 \mathrm{Cu}$ distribution showed significant variations in the euphotic zone, at the $\mathrm{Chl}$ a maximum and at bottom depths. Copper isotope ratios ranged from $+0.21 \%$ to $+0.76 \%$ o $( \pm 0.06 \%$, 2 s.d. $)$, yielding an average of $+0.51 \%$ o $( \pm 0.20 \%$, 2 s.d.; $n=96)$ for the Mediterranean Sea. A strong zonation between natural aerosol deposition to the South and anthropogenic aerosol deposition to the North was seen in the sample set (Dulaquais et al. 2017; Gerringa et al. 2017; Rolison et al. 2015). Natural dust deposits seemed to draw $\delta 65 \mathrm{Cu}$ toward lower values and deeper in the euphotic zone whereas the impact of anthropogenic aerosols seemed restricted to an increase in [dCu]T. At the $\mathrm{Chl}$ a maximum, $\delta 65 \mathrm{Cu}$ showed significant increase which we attributed to scavenging on and/or uptake by phytoplankton. The isotope signature of $\mathrm{Cu}$ sources to the Mediterranean Sea were also investigated and we inferred a significant source of isotopically heavy $\mathrm{Cu}$ in the Gibraltar area, potentially originating from a release of $\mathrm{Cu}$ sulfide leached in the mining area of Southern Spain (i.e. Iberian Pyrite Belt) in rivers and transported to the Mediterranean Sea in surface by seasonal water mass circulation. Conversely, marine sediments appear to be a source of isotopically-light Cu to deep waters. This study provides new hints on the use of copper isotopes to study sources and sinks of $\mathrm{Cu}$ in seawater. This article is part of a special issue
\end{abstract}


entitled: Conway GEOTRACES - edited by Tim M. Conway, Tristan Horner, Yves Plancherel, and Aridane G. González.

\section{Highlights}

- Improved sample preparation method and mass spectrometry technique for seawater copper isotope analysis $\left(\delta^{65} \mathrm{Cu}\right)$. Standard-bracketing used to correct for mass bias during measurement. The accuracy was evaluated via addition of NIST SRM976 to seawater. $\delta^{65} \mathrm{Cu}$ was measured in the Mediterranean Sea. $\delta^{65} \mathrm{Cu}$ seemed to vary with aerosol/riverine/sedimentary input and biological activity.

Keywords : Copper isotope, Seawater, Mediterranean Sea, Geotraces, Isotope fractionation 


\section{Introduction}

Copper $(\mathrm{Cu})$ is a key micro nutrient in seawater that contributes to photosynthesis, denitrification and iron uptake by primary producers in the food chain (Peers and Price, 2006; Peers et al., 2005; Zumft and Kroneck, 2007), but that exerts acute toxic effects on phytoplankton above a free $\mathrm{Cu}^{2+}$ level of $0.01 \mathrm{nmol} \mathrm{kg}^{-1}$ (Moffett et al., 1997). Studies have found that above this critical $\mathrm{Cu}^{2+}$ level, both prokaryotic and eukaryotic phytoplankton species release strong $\mathrm{Cu}$ complexing agents in cultures as an effective detoxification mechanism (Croot et al., 2000; Moffett and Brand, 1996; Rue and Bruland, 2001). This process might be the reason for the dissolved pool of $\mathrm{Cu}$ being mostly governed by organic complexation (95 - 99.8\%) in seawater (Coale and Bruland, 1988; Moffett and Dupont, 2007), although some eukaryotes are able to access the organically complexed pool of $\mathrm{Cu}$ (Semeniuk et al., 2015; Semeniuk et al., 2009). Total dissolved $\mathrm{Cu}$ concentrations $\left([\mathrm{dCu}]_{\mathrm{T}}\right)$ in seawater ranges from $0.3 \mathrm{nmol} \mathrm{kg}$-1 $7.6 \mathrm{nmol} \mathrm{kg}{ }^{-1}$ (Bruland and Franks, 1983; Thompson and Ellwood, 2014; Vance et al., 2008) and $\mathrm{Cu}$ has a nutrient-like profile with relatively low surface concentrations increasing with depth. This distribution is explained by plankton uptake in surface, remineralization at intermediate depths and deep-water accumulation to which is added a significant sedimentary benthic source (Jacquot and Moffett, 2015; Roshan and $\mathrm{Wu}, 2015$; Saager et al., 1992; Takano et al., 2014). A modeling study suggests that below the photic zone, dissolved $\mathrm{Cu}(\mathrm{dCu})$ is at equilibrium with falling particles and exchanges reversibly between dissolved and adsorbed state (Little et al., 2013). This process is called reversible scavenging.

Copper has two naturally occurring stable isotopes: ${ }^{63} \mathrm{Cu}(69.17 \%)$ and ${ }^{65} \mathrm{Cu}(30.83 \%)$. Natural mass-dependent variations in ${ }^{65} \mathrm{Cu} /{ }^{63} \mathrm{Cu}$ span $15 \%$, expressed relative to the NIST SRM 976 standard as $\delta^{65} \mathrm{Cu}$ values (recently reviewed in Moynier et al., 2017). 
$\delta^{65} \mathrm{Cu}=\left[\frac{\left({ }^{65} \mathrm{Cu} /{ }^{63} \mathrm{Cu}\right)_{\text {sample }}}{\left({ }^{65} \mathrm{Cu} /{ }^{63} \mathrm{Cu}\right)_{\text {SRM } 976}}-1\right] \times 1000$

Initial studies of $\mathrm{Cu}$ isotope fractionation in natural systems demonstrated the great potential of $\mathrm{Cu}$ isotopes as new tracers for the study of modern and ancient hydrothermal systems and ore deposits (Graham et al., 2004; Larson et al., 2003; Maher and Larson, 2007; Marechal et al., 1999; Mason et al., 2005; Rouxel et al., 2004; Zhu et al., 2000). So far, experimental and field studies have indicated that redox transformations between $\mathrm{Cu}(\mathrm{I})$ and $\mathrm{Cu}(\mathrm{II})$ species are the main processes resulting in $\mathrm{Cu}$ isotope fractionation in natural systems (Ehrlich et al., 2004; Mathur et al., 2005; Zhu et al., 2002). Reduced and precipitated $\mathrm{Cu}(\mathrm{I})$ species are known to be lighter by 2 to $5 \%$ relative to dissolved $\mathrm{Cu}$ (II) species (Ehrlich et al., 2004; Fujii et al., 2013; Mathur et al., 2005; Sherman, 2013; Zhu et al., 2002). Because $\mathrm{Cu}$ speciation in seawater is dominated by $\mathrm{Cu}^{2+}$ complexation with organic ligands (Coale and Bruland, 1988; Moffett et al., 1990), changes in $\mathrm{Cu}$ speciation in aqueous systems may also lead to significant $\mathrm{Cu}$ isotope fractionation (Fujii et al., 2013), with fractionation between organically complexed $\mathrm{dCu}$ and free inorganic $\mathrm{dCu}\left(\Delta^{65} \mathrm{Cu}_{\text {complex-free }}\right)$ of +0.1 to $+0.8 \%$ o (Bigalke et al., 2010; Ryan et al., 2014).

Recent studies have made an effort to measure the isotope ratio of $\mathrm{Cu}$ in seawater and its sources and sinks. In a reconnaissance study, Vance et al. (2008) reported a relatively large range of dissolved $\delta^{65} \mathrm{Cu}$ between +0.02 and $+1.45 \%$ in rivers and estuaries. Although the underlying mechanisms of $\mathrm{Cu}$ isotope fractionation in weathering environments remain unclear, isotopically heavy dissolved $\delta^{65} \mathrm{Cu}$ in rivers likely results from a balance between the preferential partitioning of light $\mathrm{Cu}$ isotopes into soils and suspended particles (Bigalke et al., 2010; Bigalke et al., 2011), with varying fractionation factors according to the importance of the mineral fraction in the soil (Babcsanyi et al., 2016), and the remobilization of isotopically light $\mathrm{Cu}(\mathrm{I})$ and reduced $\mathrm{Cu}$ from (and within) the sediments in a run-off (Babcsanyi et al., 2014). Other studies further suggest that $\mathrm{Cu}$ isotope fractionation could be useful tracers of 
$\mathrm{Cu}$ biogeochemical cycling. For example, Zhu et al. (2002) reported that the reduction and incorporation of $\mathrm{Cu}(\mathrm{II})$ within protein and yeast cells may lead to significant $\mathrm{Cu}$ isotope fractionation ( $\Delta^{65} \mathrm{Cu}_{\text {protein/yeast-source }}$ from $-1.7 \%$ to $-1.0 \%$ ) due to the incorporation of light isotopes as $\mathrm{Cu}(\mathrm{I})$ species. The preferential uptake or adsorption of heavy $\mathrm{Cu}$ isotopes onto common soil and aquatic bacteria, and marine and freshwater diatoms has been also reported, with fractionations of up to $+5.6 \%$ (Mathur et al., 2005; Pokrovsky et al., 2008). However, the direction and extent of $\mathrm{Cu}$ isotope fractionation during $\mathrm{Cu}$ adsorption on organic matterrich particles and absorption on cells remain unclear, however, and likely depend on $\mathrm{Cu}$ bonding environments and kinetic vs. equilibrium effects (Navarrete et al. (2011).

The study of the isotope fractionation of marine $\mathrm{dCu}$ is relatively new. The first dataset of dissolved $\delta^{65} \mathrm{Cu}$ in seawater from the Pacific Ocean, Indian Ocean and English Channel was published by Vance et al. (2008) and reported $\delta^{65} \mathrm{Cu}$ values ranging from +0.9 to $+1.4 \%$ ( \pm $0.1 \%$, 2 s.d.) indicating that dissolved $\delta^{65} \mathrm{Cu}$ generally exhibits higher values in open ocean than in riverine systems. More recently, Thompson et al. (2014) investigated the distribution of $\mathrm{Cu}$ isotope ratios along three vertical profiles in contrasted biogeochemical domains of the Pacific Ocean to address variations in $\delta^{65} \mathrm{Cu}$ according to marine productivity. However, only minor differences of the average $\delta^{65} \mathrm{Cu}$ were observed between the stations (from $+0.61 \pm$ $0.16 \%$ to $+0.78 \pm 0.16 \%$ ). Takano et al. (2014) also investigated several profiles in the Pacific and focused mostly on surface layers, emphasizing the role of atmospheric deposition and surface biogeochemical processes. The overall variation of $\delta^{65} \mathrm{Cu}$ in deep and surface waters observed was +0.41 to $+0.85 \%$, and the authors proposed that $\delta^{65} \mathrm{Cu}$ becomes heavier along the oceanic circulation because of preferential scavenging of ${ }^{63} \mathrm{Cu}$. The heavy isotope composition of the ocean likely results from internal processes, possibly due to isotopic partitioning between an isotopically light pool adsorbed onto particles and a heavy dissolved pool strongly bound to organic ligands (Little et al., 2014; Vance et al., 2008). 
In order to further understand $\mathrm{Cu}$ isotope fractionation in seawater, it is necessary to gather a larger dataset of $\delta^{65} \mathrm{Cu}$ encompassing several $\mathrm{Cu}$ sources and sinks, as well as different oceanic water masses and contrasting biogeochemical domains. The Mediterranean Sea is an advantageous location for this exercise, considering the semi-enclosed formation of the sea and the relatively extensive knowledge of its water masses and continental inputs (Bethoux, 1980; Millot and Taupier-Letage, 2005; Robinson et al., 2001). The Mediterranean Sea is also well-known for its enrichment in trace elements compared to the Atlantic Ocean, and its influence on the Atlantic Ocean budget of dissolved trace-metals (Boyle et al., 1985; Van Geen and Boyle, 1990; Van Geen, 1989).

In June/July 2013, the GEOTRACES-A04N section was conducted to constrain the distribution of bio-essential and other trace elements and isotope ratios in the Mediterranean and Black Seas (Rijkenberg, 2013a). Using an improved method, we present in this study the first isotope composition of $\mathrm{dCu}$ in the Mediterranean Sea from samples collected along this section. The analytical method allowed the separation of total dissolved $\mathrm{Cu}$ at low $\mathrm{pH}(1.8)$ from $1 \mathrm{~L}$ of seawater and its application to a set of inter-comparison seawater samples, including the GEOTRACES BATS samples (Boyle et al., 2012). Potential isobaric interferences and matrix effects on MC-ICP-MS were also investigated. We then report the distribution of dissolved $\delta^{65} \mathrm{Cu}$ through the water column of the Mediterranean Sea, and studied the variations of $\delta^{65} \mathrm{Cu}$ in relationship with hydrographic and biogeochemical parameters. 


\section{The Mediterranean Sea}

\subsection{Sampling}

The cruise was conducted on the RV Pelagia from May to August 2013 along the Geotraces-A04N transect in the Mediterranean Sea (Figure 1). Seawater samples were collected using the TITAN-CTD frame of the NIOZ, the Royal Netherlands Institute for Sea Research(De Baar et al., 2008), equipped with 24 ultra-clean sampling bottles of $24 \mathrm{~L}$ each made of polyvinylidene (PVDF) and titanium (Rijkenberg, 2013a; Rijkenberg, 2013b). After deployment, the TITAN system was moved to a Class-100 container for sub-sampling. Samples were filtered in-line under $\mathrm{N}_{2}$ pressure (filtered $99.99 \% \mathrm{~N}_{2}, 0.7 \mathrm{~atm}$ ) at $0.2 \mu \mathrm{m}$ using

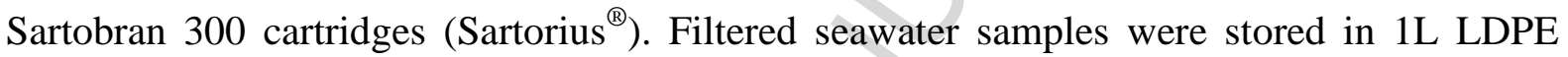
bottles (Nalgene ${ }^{\circledR}$ ) previously cleaned following the GEOTRACES procedure for trace metal analysis (Cutter et al., 2014).

Hydrographic parameters (e.g. dissolved oxygen, temperature, salinity, density) were acquired using a CTD-package. As described in Gerringa et al. (2017), it consisted of a SeaBird SBE9 plus underwater unit, a SBE11plusV2 deck unit, a SBE3plus temperature sensor, a SBE4 conductivity sensor, a Wetlabs C-Star transmissometer (25 cm, deep, red) and a SBE43 dissolved oxygen sensor. Fluorescence was measured as the beam attenuation coefficient at $660 \mathrm{~nm}$ using a Chelsea Aquatracka MKIII fluorometer. The fluorometer signal was calibrated against Chlorophyll $a$ and is expressed as $\mathrm{mg}$ Chl $a . \mathrm{m}^{-3}$. Oceanographic parameters were standardized following the Thermodynamic Equation Of Seawater - 2010 (TEOS-10) agreed upon by the Intergovernmental Oceanographic Commission (IOC), such as salinity and temperature are expressed as Absolute Salinity $\left(\mathrm{S}_{\mathrm{A}}\right.$ in $\mathrm{g} \mathrm{kg}^{-1}$ ) and Conservative Temperature (CT in ${ }^{\circ} \mathrm{C}$ ) using the Gibbs Sea Water (GSW) program (McDougall and Barker, 2011). Maps and transects were made using ODV (Schlitzer, 2016). 


\subsection{Study area}

The Mediterranean Sea is a semi-enclosed basin subject to strong evaporation (Mariotti et al., 2002), with distinct water masses showing contrasting salinity (figure 2). The Mediterranean Sea nests local hydrographic anomalies, such as the occurrence of eddies (Richardson et al., 2000), the formation of dense waters in the Gulf of Lion and in the southern Aegean Sea (Millot and Taupier-Letage, 2005), or the presence of anoxic brines in the Tyro and Bannock basins (Saager et al., 1993). The dynamic of the Mediterranean Sea is illustrated by the short residence time of the water masses, which is about 15 years for the Western Mediterranean basin and 50 years for the Eastern basin (Laubier, 2005). We expect this particularity to help constraining the sources and sinks of $\mathrm{Cu}$ rather than the long-term processes of scavenging typical of the open-ocean (Bruland and Franks, 1983).

The hydrography of the section was described by van Aken (2015) and other recent studies (Dulaquais et al., 2017; Gerringa et al., 2017; Rolison et al., 2015).

The Atlantic Ocean was sampled from stations 1 to 4 (Fig. 1 and 2). Surface Atlantic Water (SAW) flowing from $0 \mathrm{~m}$ to $200 \mathrm{~m}$ is a relatively warm, saline water mass $\left(\sigma_{\theta}<27.2 \mathrm{~kg} \mathrm{~m}^{-3}\right.$; $\mathrm{S}_{\mathrm{A}}>36.3 \mathrm{~g} \mathrm{~kg}^{-1}$; Fig. 2) entering the Mediterranean Sea above North Atlantic Central Waters (NACW) (Gascard and Richez, 1985). The underlying core of NACW flows from $200 \mathrm{~m}$ to $500 \mathrm{~m}\left(\mathrm{~S}_{\mathrm{A}}<36.3 \mathrm{~g} \mathrm{~kg}^{-1}\right.$; Fig. 2). Mediterranean Sea Outflow Water (MSOW) is the result of warm and saline Mediterranean seawater leaking through the Gibraltar Strait and mixing with fresher surface waters in the Gulf of Cadiz (Ambar and Howe, 1979; Coste et al., 1988; Howe, 1982). It is an intermediate water mass leaking into the North-East Atlantic Ocean between $750 \mathrm{~m}$ and $1250 \mathrm{~m}\left(\sigma_{\theta}=27.4\right.$ to $\left.27.8 \mathrm{~kg} \mathrm{~m}^{-3} ; \mathrm{S}_{\mathrm{A}}>36.0 \mathrm{~g} \mathrm{~kg}^{-1}\right)$ (Zenk and Armi, 1990). Below MSOW, North-East Atlantic Deep Water (NEADW) is observed between 1500 $\mathrm{m}$ to $2500 \mathrm{~m}\left(\sigma_{\theta}=27.9 \mathrm{~kg} \mathrm{~m}^{-3} ; \mathrm{S}_{\mathrm{A}}=35.2\right.$ to $\left.36.0 \mathrm{~g} \mathrm{~kg}^{-1}\right)$ with underlying Lower Deep Water 
(LDW) from $2500 \mathrm{~m}$ to the bottom $\left(\sigma_{\theta}=27.9 \mathrm{~kg} \mathrm{~m}^{-3} ; \mathrm{S}_{\mathrm{A}} \sim 35.0-35.1 \mathrm{~g} \mathrm{~kg}^{-1}\right)$ (Van Aken, 2015).

The cold, less saline Atlantic waters enter the Mediterranean Sea in surface through the Gibraltar Strait, and can be seen at station 5S from surface to $\sim 130 \mathrm{~m}$ (Fig. 2). Atlantic water travels in surface of the Mediterranean Sea and is progressively modified within the Western Mediterranean basins (WMB) to form Modified Atlantic Water (MAW) (Robinson et al., 1992; Send et al., 1999), where it lies at stations $11 \mathrm{~S}, 12 \mathrm{~N}$ and $17 \mathrm{~N}$ above $100 \mathrm{~m}$ with $\mathrm{S}_{\mathrm{A}}$ between $37.2 \mathrm{~g} \mathrm{~kg}^{-1}$ and $38.2 \mathrm{~g} \mathrm{~kg}^{-1}$ (Fig. 2). MAW extends in surface to the Eastern Mediterranean Basin (EMB) at shallower depths, with an increasing salinity of $<38.8 \mathrm{~g} \mathrm{~kg}^{-1}$ (station 21, above $70 \mathrm{~m}$; Fig. 2), describing a counter-clockwise circulation pattern along the continental coast (Millot and Taupier-Letage, 2005).

Levantine Intermediate Water (LIW), formed in the EMB, is the most saline water mass (CT $>14^{\circ} \mathrm{C} ; \mathrm{S}_{\mathrm{A}}>39.0 \mathrm{~g} \mathrm{~kg}^{-1}$ ) in the Mediterranean Sea, and is poorer in nutrients and oxygen than MAW (Millot and Taupier-Letage, 2005; Rolison et al., 2015). Within the EMB, the southern stations $18 \mathrm{~S}$ and $21 \mathrm{~S}$ are affected by the LIW between $70 \mathrm{~m}$ and $500 \mathrm{~m}$, whereas the northern stations $5 \mathrm{~N}$ and $9 \mathrm{~N}$ are affected from the surface to $800 \mathrm{~m}$ (Fig. 2). LIW is formed in winter close to the isle of Rhodes in the EMB (Millot and Taupier-Letage, 2005) and circulates counter-clockwise around the EMB, partially infiltrating the southern Adriatic Sea where station $9 \mathrm{~N}$ lies, to form in winter a dense, also saline $\left(\mathrm{S}_{\mathrm{A}}<38.9 \mathrm{~g} \mathrm{~kg}^{-1}\right)$ deep water mass, Adriatic Deep Water (AdDW) (Millot and Taupier-Letage, 2005). The rest of LIW continues flowing in the Tyrrhenian Sea through the Strait of Sicily and returns to the EMB (Millot and Taupier-Letage, 2005). Traces of LIW can be seen between $250 \mathrm{~m}$ and $1000 \mathrm{~m}$ at stations $11 \mathrm{~S}$ and $17 \mathrm{~N}$ with $\mathrm{S}_{\mathrm{A}}>38.7 \mathrm{~g} \mathrm{~kg}^{-1}$ (Gerringa et al., 2017). In each basin (WMB and EMB) exists a deeper water mass with unique hydrographic characteristics. Eastern Mediterranean Deep Water (EMDW) fills the EMB with $\mathrm{S}_{\mathrm{A}}$ around $38.9 \mathrm{~g} \mathrm{~kg}^{-1}$, affecting stations $18 \mathrm{~S}, 21 \mathrm{~S}$, 
$5 \mathrm{~N}$ and $9 \mathrm{~N}$ below $500 \mathrm{~m}$ (Fig. 2). Western Mediterranean Deep Water (WMDW) fills the deep levels of the WMB (Send et al., 1999), affecting stations 5S, $11 \mathrm{~S}$ and $17 \mathrm{~N}$ between 150 $\mathrm{m}$ and the intrusion of LIW, and below $1000 \mathrm{~m}$ to bottom with $\mathrm{S}_{\mathrm{A}}$ around $38.7 \mathrm{~g} \mathrm{~kg}^{-1}$. The main sources of freshwater to the Mediterranean Sea are limited to the Po (Italy), the Tiber (Spain), the Rhône and Ebro rivers (France), and the Nile (Egypt) (Ludwig et al., 2009). Dust input to the nutrient-depleted Mediterranean Sea is considerable in quantity and effect (Duce and Tindale, 1991; Goudie and Middleton, 2001; Guieu et al., 1991; Herut et al., 2005; Jordi et al., 2012; Ternon et al., 2011) and it is thus a natural laboratory to study the consequences of dust deposition on the surface ocean (Coale et al., 1996). A study by Jordi et al. (2012) showed that pulses of this large dust deposition in surface water are responsible for inhibiting the growth of phytoplankton population, especially considering that the atmospheric input of dissolved $\mathrm{Cu}$ to the Mediterranean basins is up to 5 times the flux of riverine inputs (Guerzoni et al., 1999).

\section{Analytical Method.}

\subsection{Chromatographic separation.}

The seawater samples were filtered through $0.2 \mu \mathrm{m}$, therefore we measured the dissolved fraction of $\mathrm{Cu}$ plus the labile fraction from fine particles under $0.2 \mu \mathrm{m}$. In this study, both fractions fall under the appellation $\mathrm{dCu}$ for simplicity. Seawater samples were then acidified to $\mathrm{pH}=1.7$ using ultrapure $\mathrm{HCl}\left(\mathrm{Optima}^{\mathrm{TM}}\right)$ in a clean shore-based laboratory. Optima-grade $\mathrm{H}_{2} \mathrm{O}_{2}$ was added to $0.03 \mathrm{wt} \%$ to enhance the dissociation of organic ligands and labile $\mathrm{Cu}(\mathrm{II})$. Samples were then left aside in the dark for 2 - 4 months before being processed.

Preparation and chromatographic purification of the samples are summarized in Table 1. All manipulations were conducted in a Class 1000 (ISO 6) clean room and all samples were 
handled inside a Class 100 (ISO 5) laminar flow hood. All Teflon and LDPE vials were acidleached prior to use. All reagents were prepared gravimetrically using distilled analytical grade acids and ultrapure water (Milli- $\left.\mathrm{Q}^{\circledR}, 18.2 \mathrm{M} \Omega\right)$. Procedural blanks and chemistry yields were assessed for each sample batch (i.e. for every 12 samples) by processing $100 \mathrm{ng}$ of $\mathrm{Cu}$ standard NIST SRM 3114.

All steps of the chemistry are summarized in Table 1. Copper pre-concentration and extraction from seawater followed a method using nitrilotriacetic acid resin (NTA Superflow ${ }^{\circledR}$, Qiagen ${ }^{\mathrm{TM}}$ ), which was previously used for measuring Fe isotope fractionation in seawater by Rouxel and Auro (2010), and was adapted from the protocol of Lohan et al. (2005). The pre-concentration process was accelerated by using a peristaltic pump set to draw seawater at a constant flow rate of $10 \mathrm{~mL} \mathrm{~min}^{-1}$ during conditioning and elution of the seawater matrix.

After recovery of the eluted sample on NTA, an aliquot of $0.4 \mathrm{~mL}$ was pipetted from the recovered sample and diluted to $20 \%$ using $18.2 \mathrm{M} \Omega$ water for preliminary $\mathrm{Cu}$ concentration determination on Multi-Collector Inductively Coupled Plasma Mass Spectrometer (MC ICPMS).

A macroporous strong base anion exchange resin AG MP-1M (100-200 mesh) (Bio Rad Inc.) was used for further separation of $\mathrm{Cu}$ from remaining elements, in particular Fe. The method essentially followed previously-established methods described in Borrok et al. (2007) and Marechal et al. (1999) (Table 1). The $\mathrm{Cu}$ fraction recovered from the AG MP-1M resin was dried down and re-dissolved in concentrated Optima ${ }^{\mathrm{TM}}$-Grade $\mathrm{HNO}_{3}$, put back to evaporation before being finally dissolved in an adjusted volume of $0.28 \mathrm{M} \mathrm{HNO}_{3}$ to obtain a final

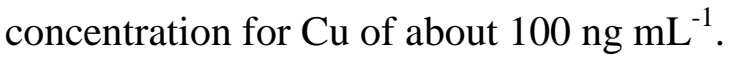




\subsection{Determination of $\mathrm{Cu}$ isotope ratios by Multicollector ICPMS.}

$\mathrm{Cu}$ concentrations and isotope ratios were analyzed using a Thermo Scientific ${ }^{\mathrm{TM}}$ Neptune Multi-collector (MC) ICPMS operated at Ifremer-Brest. The instrument was used in low mass resolution mode with high-efficiency sampler cones (Ni X-cones), and a double-pass spray chamber as the introduction system.

For each sample, the pre-determination of $\mathrm{Cu}$ concentration on MC-ICPMS using a $4 \%$ aliquot was necessary to adjust the concentration of the samples to $\sim 100 \mathrm{ng} \mathrm{mL}^{-1}( \pm 20 \mathrm{ng}$ $\mathrm{mL}^{-1}$ ) prior to analysis. This step allowed a more precise determination of $\delta^{65} \mathrm{Cu}$ and $[\mathrm{dCu}]_{\mathrm{T}}$, as all measurements were bracketed with a standard Cu NIST SRM $976\left(100 \mathrm{ng} \mathrm{mL}^{-1}\right)$.

$\mathrm{Cu}$ isotope ratios and concentrations were simultaneously measured on MC-ICPMS. Each sequence of measurement was repeated 3 to 6 times, and only average $\delta^{65} \mathrm{Cu}$ values were reported for each sample. Internal precision was calculated as the 2 Standard Deviation (s.d.) of the mean. Under typical analytical conditions, an internal precision better than $0.10 \%$ (2 s.d.) was obtained, while repeated analysis of standard NIST SRM976 gave an instrumental external precision of $0.06 \%$ on $\delta^{65} \mathrm{Cu}$ values at $95 \%$ confidence ( 2 s.d.; $\mathrm{n}=638$ ). Hence, when an internal precision ( 2 s.d.) better than $0.06 \%$ was obtained, we applied the external precision to report analytical uncertainty. Multi-elemental standard solutions were used for instrumental calibration and $\mathrm{Cu}$ concentrations were determined within $5 \%$ relative s.d..

Surface (GS) and deep (GD) seawater samples from the GEOTRACES inter-comparison stations of BATS (North Atlantic; Boyle et al.(2012)) were processed to determine the accuracy of the method. 


\section{Results}

\subsection{Isobaric interference of $\mathrm{ZnH}$ on ${ }^{65} \mathrm{Cu}$.}

Over the course of the development of the method, we used a $\mathrm{Zn}$ standard solution (SRM3168a solution) to correct for instrumental mass bias as widely used in previous studies (Albarede, 2004; Archer and Vance, 2004; Fujii et al., 2013; Marechal et al., 1999; Takano et al., 2013). This approach was however discontinued due to potential formation of Zn-hydride interferences on $\mathrm{Cu}$ isotopes. Using a desolvation nebulizer (Apex-Q; ESI), we determined the percentage of $\mathrm{Zn}$ hydride formation $\left({ }^{64} \mathrm{ZnH} /{ }^{64} \mathrm{Zn}\right)$ to be about $0.007 \%$. Because of the relatively large correction factor (up to $1.35 \%$ ) for solutions with high $\mathrm{Zn} / \mathrm{Cu}$ ratios, which is typically the case when measuring low-concentration $\mathrm{Cu}$ isotope ratios, we decided to avoid the use of $\mathrm{Zn}$ as an internal standard for instrumental mass bias correction. In a previous study, Mason et al. (2004) also reported the occurrence of a Zn-hydride interference on $\mathrm{m} / \mathrm{z}$ (mass-to-charge ratio $=65$ ) leading to shifts in ${ }^{65} \mathrm{Cu} /{ }^{63} \mathrm{Cu}$ measurement.

\subsection{Matrix effects and matrix-induced isobaric interferences.}

Isobaric interferences on $\mathrm{Cu}$ isotopes may involve double-charged ions $\left(\mathrm{Ba}^{2+}\right)$, argides $\left(\mathrm{NaAr}^{+}, \mathrm{MgAr}^{+}\right)$, and oxides $\left(\mathrm{NaOH}^{+}, \mathrm{TiO}^{+}, \mathrm{TiOH}^{+}, \mathrm{PO}_{2}^{+}, \mathrm{SO}_{2}^{+}, \mathrm{SO}_{2} \mathrm{H}^{+}, \mathrm{CaOH}^{+}, \mathrm{ClNO}^{+}\right)$ (May and Wiedmeyer, 1998). In the case of seawater analysis, Na-based, Mg-based, Cl-based and S-based ions are the most critical potential interferences. Hence, the chemical purification step is essential to avoid spectral and non-spectral interferences on MC-ICPMS. As discussed previously (Rouxel and Auro, 2010), the pre-concentration method using NTA resin removes most of these matrix elements, but an additional purification step using anion resin is often required to achieve the highest purification level. Several approaches were used to verify the achievement of interference-free measurements: (1) using the high-mass 
resolution capability of the Neptune MC-ICPMS, we checked the absence of remaining oxide and argide-based interferences on $\mathrm{Cu}$ isotopes spectra; (2) measurement of $\delta^{65} \mathrm{Cu}$ on $\mathrm{Cu}$ doped ultra-pure water gave consistent results (see section 4.3). We also measured $\mathrm{Ca}$ and $\mathrm{Mg}$ concentrations in processed seawater samples to control for the absence of remaining seawater matrix elements.

The formation of matrix-related polyatomic species during sample preparation and their introduction into the mass spectrometer may also induce non-spectral interferences. Such interferences are often referred to as matrix effects, whereby ionization efficiency and instrumental mass bias of the analyte are modified by the presence of other matrix elements. Over the course of the method development, we observed significant shifts in the $\mathrm{Cu}$ isotope ratio of the $\mathrm{Cu}$ standard ultrapure water solution when processed through the chemistry. Hence, we further investigated possible matrix effects generated by the method.

Several ultrapure water samples were processed through the entire chemistry and enriched with $\mathrm{Cu}$ SRM976 prior to analysis. In a first set of experiments, a desolvating nebulizer Apex-Q $\left(\mathrm{ESI}^{\mathrm{TM}}\right)$ was used as introduction system and instrumental mass bias was corrected using a sample-standard bracketing approach. A Ni standard solution was also used as external standard to further monitor instrumental mass bias. Results showed systematic negative shifts of the corrected $\delta^{65} \mathrm{Cu}$ values down to $-1.7 \%$ (Fig. 3), which cannot be explained by changes in instrumental mass bias since $\mathrm{Ni}$ isotope ratios remained identical within uncertainties between the samples and bracketing standard solutions (Fig. 4). This suggests that either $\mathrm{Cu}$ is the only element prone to significant matrix effects (e.g. complexation or redox effects), or that the mass 63 is affected by significant isobaric interferences. In a second set of experiments, a conventional cyclonic spray chamber was used instead of desolvating nebulizer and instrumental mass fractionation was corrected using a sample-standard bracketing approach. Results show, considering uncertainties, identical 
$\delta^{65} \mathrm{Cu}$ values between processed and unprocessed standard (Fig. 3). Hence, we propose that the dryer and hotter plasma conditions and/or the desolvating process itself are responsible for the large shift in $\mathrm{Cu}$ isotope ratio. Archer and Vance (2004) already described sudden instrumental mass bias shifts when using a desolvating nebulizer which could not be corrected by the use of $\mathrm{Zn}$ internal standard. While they suggested that a change in $\mathrm{Cu}$ oxidation state could have occurred within the introduction system, leading to its adsorption on the desolvating membrane, Bermin et al.(2006) later suggested either a mass bias artifact or the enhancement of interferences on elements in the matrix other than $\mathrm{Cu}\left(e . g .{ }^{66} \mathrm{Zn}\right) . \mathrm{In}$ the first experiment set using desolvating nebuliser, the shift in $\delta^{65} \mathrm{Cu}$ was observed regardless of the instrumental mass bias correction method (i.e. external normalization to $\mathrm{Ni}$ or sample-standard bracketing), which implies $\mathrm{Cu}$-specific interferences enhanced by the desolvating mechanism. We propose that such interferences arose from the presence of refractory organic matrices produced during the chemical purification steps that affected the behavior of $\mathrm{Cu}$ during desolvation. Post-column treatment of the samples with concentrated $\mathrm{HNO}_{3}$ and $\mathrm{H}_{2} \mathrm{O}_{2}$ did not remove such interferences. Therefore, despite the lower sensitivity (decreased by a factor of 2.5), we used a cyclonic spray chamber as sample introduction system, combined with a standard-sample-standard method to limit extensive corrections and/or interferences. In addition, the use of $\mathrm{Ni}$ or $\mathrm{Zn}$ as internal standard did not result in enhanced precision compared to a conventional standard-sample bracketing approach.

\subsection{Procedural blanks, yield and external reproducibility}

Concentrations of $\mathrm{Cu}, \mathrm{Ni}$ and $\mathrm{Zn}$ were measured on each procedural blanks and sample solutions for contamination control. Procedural blanks were estimated by using $1 \mathrm{~L}$ of ultrapure water acidified to $\mathrm{pH} 1.8$ and passed through the entire process. The resulting $\mathrm{Cu}$ blanks 
mostly ranged between $2.2 \mathrm{ng}$ and $3.7 \mathrm{ng}(\mathrm{n}=5)$, and therefore account for less than $2.4 \%$ of typical open-ocean $\mathrm{Cu}$ concentrations.

The yield for $\mathrm{Cu}$ recovery was assessed using a standard-addition method. This approach has been already used in several metal isotope fractionation studies in seawater (Rouxel and Auro, 2010; Takano et al., 2013). It consists in adding incremental amounts of a standard solution of known concentration and isotope ratios, in this case Cu SRM3114 to an unknown seawater sample. Here, we used an open deep Pacific seawater sample sampled recovered off Hawaii (cruise KM0923, October 2009). The relationships between measured $\delta^{65} \mathrm{Cu}$ values and the percentage of $\mathrm{Cu}$ added to the composite samples are shown in Fig. 5. The correlation line defines two end-members: (1) $\delta^{65} \mathrm{Cu}$ of the standard SRM3114 at the intercept, i.e. -0.06 $\pm 0.02 \%$ (2s.e.); (2) $\delta^{65} \mathrm{Cu}$ of the seawater sample, extrapolated at $100 \%$ (i.e. $\mathrm{Cu}_{\mathrm{sw}} / \mathrm{Cu}_{\mathrm{mes}}=1$ ) and measured at $0.50 \pm 0.08 \%$ (2s.d.). Previous value for the intercept was calculated using the least square function LINEST (Excel, Microsoft), and associated error was adapted to be at 2 s.e.. Considering that SRM3114 has a $\delta^{65} \mathrm{Cu}$ value of $-0.054 \pm 0.05 \%$ (2s.d.; $\mathrm{n}=7$ ), the standard addition method gave consistent results. When comparing concentration of total $\mathrm{Cu}$ measured vs. the theoretical concentration of Cu SRM3114 used, we determined a recovery of $\mathrm{Cu}$ on the NTA resin of about $96.5 \%( \pm 5 \%)$. Copper concentration in the bulk seawater was measured at $0.48 \pm 0.01 \mathrm{nmol} \mathrm{kg}$, which is consistent with published values for North Pacific surface water (Biller and Bruland, 2012; Bruland, 1980). Hence, it can be suggested that the chemical procedure does not fractionate $\mathrm{Cu}$, even though this method may not fully recover about $5 \%$ of $\mathrm{Cu}$ initially present in the sample.

Due to the limited volume of seawater available for the study, the external reproducibility could not be determined via replication of seawater samples. Instead, we measured replicates of ultra-pure water enriched with $\mathrm{Cu}$ standard SRM3114. The average $\delta^{65} \mathrm{Cu}$ determined was $-0.10 \pm 0.06 \%$ ( 2 s.d.; $n=12$ ), giving a precision for the method of $0.06 \%$. This result is 
similar to the non-processed $\delta^{65} \mathrm{Cu}$ value of SRM $3114\left(\delta^{65} \mathrm{Cu}=-0.06 \pm 0.02 \%\right.$ o, 2 s.d., $n=44)$.

\subsection{Inter-comparison samples}

We processed two GEOTRACES North Atlantic Inter-calibration 2008 reference samples from the Bermuda Station, surface and deep water (respectively GS and GD), for which $[\mathrm{dCu}]_{\mathrm{T}}$ consensus values agreed upon by 10 different laboratories using various methods are available

at https://websites.pmc.ucsc.edu/ kbruland/GeotracesSaFe/2012GeotracesSAFeValues/GEOTR ACES_Ref_Cu.pdf. As part of the inter-comparison exercise, $\delta^{65} \mathrm{Cu}$ was measured on these samples by Boyle et al. (2012) and Takano et al. (2014) (Table 2).

The values for $[\mathrm{dCu}]_{\mathrm{T}}$ and $\delta^{65} \mathrm{Cu}$ obtained using our method are very similar between the Atlantic station 1 and our measurements of BATS samples. The surface samples gave $[\mathrm{dCu}]_{\mathrm{T}}$ of $0.8-0.9 \mathrm{nmol} \mathrm{kg}{ }^{-1}$ with $\delta^{65} \mathrm{Cu}$ of $+0.4 \%$, and the deep seawater samples displayed higher values for $[\mathrm{dCu}]_{\mathrm{T}}\left(1.38 \mathrm{nmol} \mathrm{kg}{ }^{-1}\right)$ and $\delta^{65} \mathrm{Cu}(+0.6 \%$ ) (Table 2).

Some disparities appeared when comparing our data to the GEOTRACES consensus values. We measured $[\mathrm{dCu}]_{\mathrm{T}}$ at a concentration $11-15 \%$ inferior to the consensus values for GD, and $\delta^{65} \mathrm{Cu} \sim 30 \%$ lighter than that measured by Boyle et al. (2012) for GS and $\sim 50 \%$ heavier than that measured by Takano et al. (2014) for GD.

Recent studies focussed on the effect of UV-oxidation pre-treatment on the variability in $[\mathrm{dCu}]_{\mathrm{T}}$ in seawater samples (Middag et al., 2015; Posacka et al., 2017). As numerous authors demonstrated, e.g. Milne et al. (2010), Biller and Bruland (2012), 1hr of UV-oxidation increases $[\mathrm{dCu}]_{\mathrm{T}}$ by $\sim 10 \%$ by breaking down organic metal-binding ligands, which motivated a new assessment of the consensus values for GS and GD (Table 2). However, Posacka et al. (2017) showed that UV-oxidation is mostly effective on $[\mathrm{dCu}]_{\mathrm{T}}$ in samples acidified less than 
2 months prior to analysis, and suggest that UV-oxidation might not be necessary for samples stored for a long period of time (i.e. $\geq 4$ years). In this study, our inter-comparison samples GS ( 7 m) and GD ( 2000 m) were acidified and stored for 6 years prior to analysis, and $[\mathrm{dCu}]_{\mathrm{T}}$ reported for GS is similar between our study and the 2011 and 2013 consensus values (Table 2). All BATS samples GS and GD from 2008 are exhausted, so the discrepancy in $[\mathrm{dCu}]_{\mathrm{T}}$ between our deep-water sample GD and the consensus values cannot be investigated. Therefore, we do not dismiss the possibility that in our GD sample, $\mathrm{Cu}$-binding ligands were not quantitatively broken down by an extensive period of storage at low $\mathrm{pH}$ and addition of $\mathrm{H}_{2} \mathrm{O}_{2}$. Thompson et al. (2013) also tested the impact of UV-oxidation and addition of $\mathrm{H}_{2} \mathrm{O}_{2}$ prior to extraction with no conclusive effect on $\delta^{65} \mathrm{Cu}$ compared to un-manipulated samples. Authors Little et al. (2018) report variations up to $\sim 30 \%$ in $[\mathrm{dCu}]_{\mathrm{T}}$ between a measurement via UV-High resolution technique, and a measurement via beam matching with standards of known concentration (similar to this study), and confirm the absence of significant effect on $\delta^{65} \mathrm{Cu}$.

At the moment, we cannot further investigate the discrepancies in $[\mathrm{dCu}]_{\mathrm{T}}$ and $\delta^{65} \mathrm{Cu}$ between our data and reported values, for the reasons mentioned earlier. Increased collaboration between laboratories would be necessary to determine whether the samples used as intercomparison were not homogeneous or whether there are analytical issues to be overcome.

In this study, $[\mathrm{dCu}]_{\mathrm{T}}$ is reported within $10 \%$ error, taking into account the possible nonquantitative degradation of organic ligands and $\mathrm{dCu}$. Furthermore, standard addition test and comparison to literature gives us confidence in our isotopic data.

\subsection{Dissolved $\mathrm{Cu}$ concentration and isotope ratio in the Mediterranean Sea}

We investigated the distribution of $\mathrm{Cu}$ concentrations and isotope ratios of 97 samples from 11 stations across the Mediterranean Sea, representing a subset of seawater samples 
collected during the GEOTRACES-A04N cruise. Depth resolution varied anywhere from 10 $\mathrm{m}$ to $1000 \mathrm{~m}$ and sampling depths were selected to capture the main hydrographic structures. All data and complementary hydrographic parameters are available in Table 3.

Dissolved $\mathrm{Cu}$ concentrations varied between $0.72 \mathrm{nmol} \mathrm{kg}^{-1}$ (station $3 ; 75 \mathrm{~m}$ ) and $6.00 \mathrm{nmol}$ $\mathrm{kg}^{-1}$ (station $\left.9 \mathrm{~N} ; 10 \mathrm{~m}\right)$. Most of the variations occurred above $200 \mathrm{~m}$ and near the benthic layer. Seawater below $200 \mathrm{~m}$ displayed an eastward increase in average $[\mathrm{dCu}]_{\mathrm{T}}$, from 1.27 $\mathrm{nmol} \mathrm{kg}{ }^{-1}\left( \pm 0.51 \mathrm{nmol} \mathrm{kg}{ }^{-1}, 1\right.$ s.d.; $\left.\mathrm{n}=10\right)$ in the Atlantic to $1.91 \mathrm{nmol} \mathrm{kg}^{-1}\left( \pm 0.40 \mathrm{nmol} \mathrm{kg}{ }^{-1}\right.$, 1s.d.; $\mathrm{n}=16)$ in the EMB.

High $[\mathrm{dCu}]_{\mathrm{T}}$ were measured at stations 5S $(10 \mathrm{~m}), 11 \mathrm{~S}(40 \mathrm{~m}), 21 \mathrm{~S}(85 \mathrm{~m})$ and $9 \mathrm{~N}(10 \mathrm{~m})$. In the Alboran Sea (station 5S), $[\mathrm{dCu}]_{\mathrm{T}}$ in the inflowing Atlantic seawater (surface to $130 \mathrm{~m}$ ) is about 2 to 3 times the concentration found at similar depths in the Atlantic stations 1 to 4 , with a corresponding $\delta^{65} \mathrm{Cu}$ up to $+0.68 \%$. Comparatively high surface $[\mathrm{dCu}]_{\mathrm{T}}$ was reported by Van Geen (1989) at a similar location in the Alboran Sea. Surface waters at station 11S were affected by heavy rains and eddies during sampling (Dulaquais et al., subm.), possibly explaining the peculiar sub-surface $[\mathrm{dCu}]_{\mathrm{T}}$ maxima of $4.30 \mathrm{nmol} \mathrm{kg}{ }^{-1}$ and $\delta^{65} \mathrm{Cu}$ minima of $+0.23 \%$ measured at $40 \mathrm{~m}$. The highest $[\mathrm{dCu}]_{\mathrm{T}}$ in the Mediterranean Sea is found at station $9 \mathrm{~N}$ in surface water $\left(6.00 \mathrm{nmol} \mathrm{kg}{ }^{-1}\right)$, for which high concentrations of dissolved $\mathrm{Cu}$ and other trace elements (e.g. Zn, Mn, Co) have been observed at a similar depth (Zago et al., 2002). We do not have an explanation for the high $[\mathrm{dCu}]_{\mathrm{T}}$ observed at $\mathrm{Chl} a$ maximum at station $21 \mathrm{~S}$, and do not exclude the possibility of contamination of the sample.

In general, at all Atlantic stations (i.e. stations 1 to 4), the vertical distribution of $[\mathrm{dCu}]_{\mathrm{T}}$ was consistent with the profiles reported elsewhere in the Atlantic sector (Jacquot and Moffett, 2015; Roshan and $\mathrm{Wu}, 2015)$, with $[\mathrm{dCu}]_{\mathrm{T}}$ increasing with depth below the surface mixed layer (SML) (Fig. 6). An increase of $\delta^{65} \mathrm{Cu}$ is observed with depth, with deep water masses carrying heavier $\delta^{65} \mathrm{Cu}(+0.60 \%$; NEADW, LDW; Fig. 6) than sub-superficial and 
intermediate water masses (+0.45\%; SAW, NACW; Fig. 6). Little et al. (2018) report an average $\delta^{65} \mathrm{Cu}$ of $+0.66 \pm 0.07 \%$ o $(\mathrm{n}=39$, 1s.d. $)$ below $200 \mathrm{~m}$ for stations in the South Atlantic, highlighting the homogeneous composition of the deep Atlantic waters in $\delta^{65} \mathrm{Cu}$.

Profiles of $[\mathrm{dCu}]_{\mathrm{T}}$ in the WMB stations (i.e. stations $5 \mathrm{~S}, 11 \mathrm{~S}, 12 \mathrm{~N}, 13 \mathrm{~N}, 17 \mathrm{~N}$ ) have an average value of $1.64 \pm 0.33 \mathrm{nmol} \mathrm{\textrm {kg } ^ { - 1 }}(\mathrm{n}=25 ; 1 \mathrm{s.d})$ below $200 \mathrm{~m}$, and show no clear variations between MAW, WMDW and LIW (fig. 6). The profiles and range of $\mathrm{Cu}$ concentrations in the WMB stations are in accordance with previous Mediterranean studies by e.g. Boyle et al. (1985), Laumond et al. (1984), Morley et al., (1997) and Yoon et al. (1999).

The profiles and range of $[\mathrm{dCu}]_{\mathrm{T}}$ at stations $18 \mathrm{~S}$ and $5 \mathrm{~N}$ are comparable to data reported by Saager et al. (1993) in the Bannock basin. However, the profile of $[\mathrm{dCu}]_{\mathrm{T}}$ at station $21 \mathrm{~S}$ (comparatively Tyro basin) does not compare to Saager et al. (1993). The authors proposed that the occurrence of anoxic brines in the Tyro basin may explain the large variations of $[\mathrm{dCu}]_{\mathrm{T}}$ observed in deep water, however station $21 \mathrm{~S}$ does not show the presence of such a brine.

Copper isotope ratios range from $+0.21 \%$ (station $21 \mathrm{~S} ; 10 \mathrm{~m}$ ) to $+0.76 \%$ (station $21 \mathrm{~S} ; 1249$ m) (Table 3, Fig. 6). A number of low $\delta^{65} \mathrm{Cu}$ values, from $+0.21 \%$ to $+0.37 \%$, were found within the euphotic zone $(0-200 \mathrm{~m})$ at Atlantic station 4 and in the Southern Mediterranean stations 5S to 21S. Profiles of $\delta^{65} \mathrm{Cu}$ showed a significant increase at the Chl $a$ maximum within the Atlantic stations and Southern Mediterranean stations, with a non-systematic decrease in $[\mathrm{dCu}]_{\mathrm{T}}$. Benthic variations in $\mathrm{dCu}$ and $\delta^{65} \mathrm{Cu}$ were noted at stations $11 \mathrm{~S}, 18 \mathrm{~S}$ and $5 \mathrm{~N}$ with no systematic trend between the two parameters. The vertical distribution of $\delta^{65} \mathrm{Cu}$ were comparable to published profiles from Thompson et al. (2014; 2013), Takano et al. (2013; 2014) and Little et al. (2018), with $\delta^{65} \mathrm{Cu}$ ranging from $+0.46 \%$ to $+0.99 \%$. 


\section{Discussion}

\subsection{Comparison between methods}

In order to measure $\delta^{65} \mathrm{Cu}$ in open seawater, several analytical challenges must be overcome. Because $\mathrm{dCu}$ concentrations in natural seawater are generally below $1 \mathrm{nmol} \mathrm{kg}{ }^{-1}, \delta^{65} \mathrm{Cu}$ should be determined on $50 \mathrm{ng}$ or less of $\mathrm{Cu}$. Procedural blanks must be less than 1 to $2 \mathrm{ng}$ so that their contribution to the measured $\delta^{65} \mathrm{Cu}$ values are negligible. The natural variability in $\mathrm{Cu}$ isotope ratios is also expected to be in the per mil range, so an analytical precision of about $0.1 \%$ ( 2 s.d.) should be achieved. Another critical analytical aspect is the necessity to avoid isobaric interferences and matrix effects during mass spectrometric analysis. Several approaches have been recently reported for carrying out the pre-concentration steps required to measure the $\mathrm{Cu}$ isotope ratio of $\mathrm{dCu}$ in seawater: 1) organic solvent extraction with chloroform (Boyle et al., 2012; Thompson and Ellwood, 2014; Thompson et al., 2013); 2) $\mathrm{Mg}(\mathrm{OH})_{2}$ co-precipitation (Bermin et al., 2006; Vance et al., 2008); 3) use of a chelating resin (Chelex-100 or Nobias-chelate PA-1 resins, (Bermin et al., 2006; Takano et al., 2013). We found that the use of NTA-resin offers the advantage of efficiently discarding major components of the seawater matrix (e.g. S, Si, Ca) as well as trace elements (e.g. Ni, Zn,), while providing a great recovery for $\mathrm{Cu}$ in acidic seawater (Rouxel and Auro, 2010).

Previous studies have widely used $\mathrm{Zn}$ isotopes to correct for instrumental mass bias, thereby allowing to report $\delta^{65} \mathrm{Cu}$ after an internal normalization step (Archer and Vance, 2004; Marechal et al., 1999; Zhu et al., 2000). This method implies that $\mathrm{Zn}$ and $\mathrm{Cu}$ isotopes are fractionated in a similar manner during MC-ICPMS measurements, which is valid in most cases, or could be assessed by measuring the relationships between $\mathrm{Zn}$ and $\mathrm{Cu}$ instrumental mass fractionation factors over the course of the analytical session. In practice, this method is also used in conjunction to the so-called standard-sample bracketing method (Takano et al., 
2013). It is, however, important to note that this method is prone to potential isobaric interferences or matrix effects, especially considering that both $\mathrm{Cu}$ and $\mathrm{Zn}$ isotope systems must be free of artifacts. In some instances, $\mathrm{Ni}$ has been used in place of $\mathrm{Zn}$ to correct for mass bias (Boyle et al., 2012; Thompson and Ellwood, 2014; Thompson et al., 2013). We evaluated the potential analytical artifacts and discussed the robustness of our method (sections 4.1-4.2). The overall outcome is that sample-standard bracketing technique yields similar, if not better, external precision compared to Zn-doping, with a 2 s.d. of about 0.06 $\%$. The use of a standard-sample bracketing with no external addition of $\mathrm{Zn}$ or Ni remains a simpler way to correct for mass-bias without introducing further correction, in particular from Zn-hydride interferences, which is required when measuring sample solutions with high $\mathrm{Zn} / \mathrm{Cu}$ ratios (i.e, optimal conditions for low $\mathrm{Cu}$ concentrations). The exclusive use of a spray chamber was also proven to be critical to avoid potential matrix-induced artifacts in $\mathrm{Cu}$ isotope analysis, which cannot be corrected using internal standardization using either $\mathrm{Zn}$ or Ni.

\subsection{Distribution of $\mathrm{Cu}$ and $\delta^{65} \mathrm{Cu}$ in the Mediterranean Sea and Atlantic Ocean}

\subsubsection{Variations of $\mathrm{Cu}$ and $\delta^{65} \mathrm{Cu}$ in the euphotic zone: atmospheric input.}

Copper concentrations and isotope ratios varied mostly within the top $200 \mathrm{~m}$ in the Mediterranean Sea stations. Southern stations were sporadically affected by low $\delta^{65} \mathrm{Cu}$ in sub-surface and peaks in $\delta^{65} \mathrm{Cu}$ at depth of $\mathrm{Chl} a$ maximum, while Northern stations showed more constant profiles of $[\mathrm{dCu}]_{\mathrm{T}}$ and $\delta^{65} \mathrm{Cu}$ around $1.86 \pm 0.24 \mathrm{nmol} \mathrm{kg}^{-1}$ and $+0.49 \pm 0.07 \%$ (1s.d., $\mathrm{n}=14$ ). Such variations could be linked to $\mathrm{dCu}$ sensitivity to aerosol deposition, river input and/or biological activity, each hypothesis being discussed in the following sections 5.2.1 to 5.2.3 respectively. 
Can aerosol deposition be responsible for the low $\delta^{65} \mathrm{Cu}$ observed at stations $4,11 \mathrm{~S}, 18 \mathrm{~S}, 21 \mathrm{~S}$ in surface and down to $125 \mathrm{~m}$ ? If so, why would Northern stations not be affected by it?

Dissolved $\mathrm{Cu}$ shows a clear enrichment in surface waters along a SW-NE gradient (Fig. 7). A similar pattern was reported for $\mathrm{dAl}, \mathrm{dFe}$ and $\mathrm{dCo}$ within the same sample set, which was attributed to the dissolution of aerosols in the EMB along the counter-clockwise circulation of the MAW (Dulaquais et al., 2017; Gerringa et al., 2017; Rolison et al., 2015). The Hybrid Single-Particle Lagrangian Integrated Trajectory (HYSPLIT) model for back trajectory analysis was used to track the origin of aerosol deposition in the Northern and Southern stations (see Supplement figure 1). The model showed that during sampling, the Northern stations were under the influence of the highly-industrialized and populated Western Europe whereas the Southern stations were under the influence of Northern Africa, i.e. the Saharan desert. Preferential deposition of natural Saharan dust in the Southern Mediterranean Sea and anthropogenic aerosol deposition in the Northern Mediterranean Sea are also reported by Rossini et al. (2001).

The Saharan desert is a prominent source of trace metals to the oceans. Global $\delta^{65} \mathrm{Cu}$ of the soluble fraction of wet and dry atmospheric deposition is about $0.0 \%$, which is estimated from a range of $-0.18 \%$ to $+0.3 \%$ (Dong et al., 2013; Little et al., 2014; Takano et al., 2014). Such a value reflects the primary lithogenic origin of $\mathrm{Cu}$ in Saharan mineral dust. Aerosol deposition from the Sahara would therefore be a source of isotopically lighter $\mathrm{dCu}$ to the upper column in the Gibraltar Strait and Southern Mediterranean stations. When taking into account the accumulation of atmospheric input along the MAW, the rapid mixing of the water masses in the basin and the slow dissolution of natural aerosols in seawater (Mackey et al., 2014), the signature of this natural aerosol input could possibly be seen down to $125 \mathrm{~m}$ in station $18 \mathrm{~S}$. 
Equation (1) gives the fraction of $\delta^{65} \mathrm{Cu}\left(\mathrm{f}_{\mathrm{Cu}}\right)$ contributed from each of the mineral dust and Atlantic seawater components to the surface waters in the Southern Mediterranean Sea:

$$
f_{C u}=\frac{\left(\delta^{65} \mathrm{Cu}_{M B}-\delta^{65} \mathrm{Cu}_{A t l}\right)}{\left(\delta^{65} \mathrm{Cu}_{a t m}-\delta^{65} \mathrm{Cu}_{A t l}\right)}
$$

Using an average $\delta^{65} \mathrm{Cu}$ for surface values in the Atlantic $\left(\delta^{65} \mathrm{Cu}_{\mathrm{Atl}}=+0.42 \%\right.$ ), an atmospheric $\delta^{65} \mathrm{Cu}$ of $0 \%$ o $\left(\delta^{65} \mathrm{Cu}_{\mathrm{atm}}\right)$, and all $\delta^{65} \mathrm{Cu}$ inferior to $\delta^{65} \mathrm{Cu}_{\mathrm{Atl}}$ from surface to $125 \mathrm{~m}$ at stations $4,11 \mathrm{~S}, 18 \mathrm{~S}$ and $21 \mathrm{~S}\left(\delta^{65} \mathrm{Cu}_{\mathrm{MB}}\right)$, we calculated that Saharan dust could contribute up to $50 \%$ (station $21 \mathrm{~S}, 10 \mathrm{~m}$ ) to $\delta^{65} \mathrm{Cu}$ in surface waters in the Southern Mediterranean Basins.

Numerous studies showed that the solubility of $\mathrm{Cu}$ in aerosols is superior from anthropogenic sources vs. mineral sources (respectively 10-100 \% against 1-7 \%) (Desboeufs et al., 2005; Hsu et al., 2005; Jordi et al., 2012; Sholkovitz et al., 2010), which could be seen in the superficial enrichment in $\mathrm{dCu}$ in the Northern basins (Fig. 7). Aerosols of anthropogenic origin contain carbon-containing particles (issued in part from fossil fuel combustion, biomass burning and ship traffic), sea-salt particles and secondary organic aerosol (Arndt et al., 2017; Mallet et al., 2016), as opposed to mineral phases in natural dust. Gonzalez et al. (2016) measured $\delta^{65} \mathrm{Cu}_{\mathrm{AE} 633}$ from $+0.04 \%$ to $+0.97 \%$ ( $\pm 0.21 \%$, 2s.d.) in atmospheric particulate matter in two European cities (London and Barcelona), and inferred a correlation between sources of fossil fuel combustion (traffic and domestic/industrial combustion) and the heavy isotope composition of the particles. As a side note, the newly certified standard ERM $^{\circledR}$ AE633 is comparable to the standard NIST SRM 976 (Moeller et al., 2012). The Northern stations could therefore see an atmospheric input of $\mathrm{dCu}$ with a heavier isotope composition than the Southern stations.

The highest surface $[\mathrm{dCu}]_{\mathrm{T}}$ was measured at station $9 \mathrm{~N}\left(6.00 \mathrm{nmol} \mathrm{kg}{ }^{-1}\right)$, the closest to the coast. High concentrations in surface waters of $\mathrm{dCu}$ and other trace elements (e.g. $\mathrm{Zn}, \mathrm{Mn}$, 
Co) have previously been reported (Zago et al., 2002) and linked to significant atmospheric deposition (Guerzoni et al., 1999; Rossini et al., 2001) and river input (Tankere and Statham, 1996). The sampling was done on July $31^{\text {st }} 2013$, when forest fires were detected close to the location of the station (Arndt et al., 2017). Organic-rich aerosol deposits were therefore expected at station $9 \mathrm{~N}$, and $\delta^{65} \mathrm{Cu}$ measured in surface $(+0.51 \%)$ further supports the idea that atmospheric deposition of non-lithogenic origin (here ashes) could carry a heavier isotope composition to the surface waters than lithogenic matter from dust aerosols.

\subsubsection{Variations of $\mathrm{Cu}$ and $\delta^{65} \mathrm{Cu}$ in the euphotic zone: river input.}

The inflow of surface Atlantic water across the Gibraltar Strait has been shown to bring a significant pool of trace metals (e.g. $\mathrm{Cu}, \mathrm{Zn}, \mathrm{Cd}, \mathrm{Ni}$ and Co) (Van Geen et al., 1988) (Fig. 7). More specifically, Spanish Shelf Water (SSW) is a surface water mass that connects the Gulf of Cadiz to the Gibraltar Strait during summer time, and is responsible for enriching the Atlantic inflow of $\mathrm{dCu}$ by a factor of 2 (Elbaz-Poulichet et al., 2001). Such enrichment originates within the Gulf of Cadiz, which is fed by the Rio Tinto and the Rio Odiel, two low$\mathrm{pH}$ rivers draining the Iberian Pyrite Belt, a massive sulfide deposit located Southern Spain and Portugal (Elbaz-Poulichet et al., 1999; Nelson and Lamothe, 1993; Van Geen et al., 1997). The Iberian Pyrite Belt is a historical mining site enriched in $\mathrm{Cu}$ sulfides (mostly chalcopyrite). In a similar context, Kimball et al. (2009) measured $\delta^{65} \mathrm{Cu}$ and $[\mathrm{dCu}]$ in an acidic stream, leaching exposed chalcopyrite and enargite from abandoned mines in southwestern Colorado. The authors found that acid leaching of $\mathrm{Cu}$-enriched minerals leads to the preferential loss of ${ }^{63} \mathrm{Cu}$ to the surface of the dissolving mineral, leaving the solution enriched in isotopically heavy $\mathrm{dCu}$, such as $\Delta^{65} \mathrm{Cu}_{\text {(solution-mineral) }}$ ranges between $+0.98 \%$ and +3.00\% (Kimball et al., 2009; Mathur et al., 2005; Wall et al., 2007). 
Station $5 \mathrm{~S}$ showed higher $[\mathrm{dCu}]_{\mathrm{T}}$ and heavier $\delta^{65} \mathrm{Cu}$ in the top $60 \mathrm{~m}$ compared to the surface waters in the Atlantic stations (Fig. 6, Table 3). In order to determine whether $\mathrm{Cu}$ concentration and isotopic composition in surface waters at station $5 \mathrm{~S}$ may result from mixing of Atlantic $\mathrm{Cu}$ and $\mathrm{Cu}$ from the Iberian Pyrite Belt, we used the following mass balance equation (equation 2):

$$
\delta^{65} C u_{S T N} 5 S=\delta^{65} C u_{S S W} \times F_{S S W}+\delta^{65} C u_{A t l .} \times F_{A t l} .
$$

Where $F$ is the relative contribution of the SSW and the Atlantic water masses to the surface waters in the Gibraltar Strait (i.e. $81 \pm 6 \%$ for the Atlantic water masses, and $18 \pm 4 \%$ for the SSW) (Elbaz-Poulichet et al., 2001), $\delta^{65} \mathrm{Cu}_{\text {STN 5S }}$ is the averaged $\delta^{65} \mathrm{Cu}$ from the top $60 \mathrm{~m}$ at station $5 \mathrm{~S}$ (i.e. $+0.61 \pm 0.14 \%$ ), $\delta^{65} \mathrm{Cu}_{\text {Atl. }}$ is the averaged $\delta^{65} \mathrm{Cu}$ from Atlantic surface water (i.e. $+0.42 \pm 0.07 \%$; station 1 and BATS; this study) and $\delta^{65} \mathrm{Cu}_{\mathrm{SSw}}$ is the original $\delta^{65} \mathrm{Cu}$ of SSW. Modifying equation 2 to extract $\delta^{65} \mathrm{Cu}$ from SSW at station 5S gives equation 3:

$$
\delta^{65} C u_{S S W}=\frac{\delta^{65} C u_{S T N 5 S}-\delta^{65} C u_{A t l .} \times F_{A t l}}{F_{S S W}}
$$

The resulting $\delta^{65} \mathrm{Cu}$ for SSW is $+1.52 \pm 0.24 \%$. Measurements of $\delta^{65} \mathrm{Cu}$ in acidic streams leaching $\mathrm{Cu}$ sulfide minerals range from $+1.38 \%$ to $+1.69 \%$ (Borrok et al., 2008; Kimball et al., 2009), which reinforce the validity of the calculated $\delta^{65} \mathrm{Cu}$. However, Borrok et al. (2008) measured $\delta^{65} \mathrm{Cu}$ in freshwater upstream the Rio Tinto and Rio Odiel and found lighter values, respectively $-0.45 \%$ and $-0.74 \%$. These values are similar to $\delta^{65} \mathrm{Cu}$ from acidleaching experiments done on chalcopyrite in the presence of Acidithiobacillus ferrooxidans (dead and alive) from Kimball et al. (2009). We suggest that the potential presence of such bacteria at the sites of sampling may have affected the resulting $\delta^{65} \mathrm{Cu}$ of the Rio Tinto and Rio Odiel in Borrok et al. (2008), and that the reported $\delta^{65} \mathrm{Cu}$ may not be representative of the whole rivers. Finally, we cannot dismiss that heavy $\delta^{65} \mathrm{Cu}$ measured in surface waters at station $5 \mathrm{~S}$ may result from further isotopic exchange between particulate and dissolved $\mathrm{Cu}$ 
pools downstream, as previously observed in riverine systems (Vance et al., 2008). Direct measurement of $\delta^{65} \mathrm{Cu}$ in the SSW and downstream the Rio Tinto and the Rio Odiel would be necessary to confirm the calculated value. However, if the similarity of the calculated $\delta^{65} \mathrm{Cu}$ value of SSW to the Borrok et al. (2008) (Fisher Creek) and Kimball et al. (2009) results is meaningful, we may suggest that: (1) $\mathrm{Cu}$ transported by the SSW might carry the isotopic signature of $\mathrm{Cu}$ sulfide acidic leachate, presumably originating from the Iberian Pyrite Belt; (2) the signature of $\mathrm{Cu}$ from the Iberian Pyrite Belt may be seen as far away as the Alboran Sea.

For the other stations within the WMB and EMB, salinity values at all stations suggest the absence of a direct influence of riverine input (Fig. 2).

\subsubsection{Variations of $\mathrm{Cu}$ and $\delta^{65} \mathrm{Cu}$ in the euphotic zone: biological activity.}

The Mediterranean Sea is oligotrophic, and the $\mathrm{Chl} a$ concentrations at the $\mathrm{Chl} a$ maximum varied between 0.09 and $0.67 \mathrm{mg} \mathrm{m}^{-3} \cdot \delta^{65} \mathrm{Cu}$ showed significant increase by up to $0.5 \%$ in the Chl $a$ maximum in the Atlantic stations (stations 3,4) and the Southern Mediterranean stations (stations 5S, 11S, 18S and 21S). Little et al. (2018) also reported isotopically heavy $\mathrm{dCu}$ in the $\mathrm{Chl} a$ maximum in two eutrophic stations in the South Atlantic. The authors suggested that the preferential uptake of the light isotope and/or stabilization of the heavy isotope in solution could lead to isotopically heavier $\mathrm{dCu}$ in solution.

The light isotope ${ }^{63} \mathrm{Cu}$ tends to adsorb onto particles or be taken up as a nutrient by phytoplankton as $\mathrm{Cu}(\mathrm{I})$ (Sherman, 2013; Zhu et al., 2002). Such a loss of light isotope ${ }^{63} \mathrm{Cu}$ to phytoplankton (by uptake or sinking onto particles) could therefore explain the increase in $\delta^{65} \mathrm{Cu}$ at $\mathrm{Chl}$ a maximum. Additionally, marine phytoplankton produce extracellular $\mathrm{Cu}-$ ligands of various conditional stability constant, i.e. $\log \mathrm{K}=12-14 \mathrm{M}^{-1}$ for class 1-ligands, and $\log \mathrm{K}=9-12 \mathrm{M}^{-1}$ for class 2-ligands (Croot et al., 2000; Pistocchi et al., 2000; Schreiber et 
al., 1990), resulting in the near complete organic complexation of $\mathrm{Cu}^{2+}$ in the dissolved pool. Ryan et al. (2014) showed organic ligands preferentially complex the heavy $\mathrm{Cu}$ isotope in solution, conferring it higher stability as $\mathrm{dCu}$.

Interestingly, we noted that the stations presenting the lowest Chl $a$ concentrations (stations $18 \mathrm{~S}, 21 \mathrm{~S}, 9 \mathrm{~N}, 12 \mathrm{~N}$ and $13 \mathrm{~N})$ presented the highest $\delta^{65} \mathrm{Cu}$ average within the euphotic zone $(+0.54 \pm 0.07 \%$, 1 s.d.; $\mathrm{n}=17)$ when compared to stations of higher Chl $a$ content $(+0.44 \pm$ $0.08 \%$, 1s.d.; $\mathrm{n}=29$ ) (extreme values excluded). The disparity between the two averages is small, but might nonetheless reflect the remineralization process at work at stations of higher productivity. It is worth noting that the Mediterranean Sea stations do not show much variations in $[\mathrm{dCu}]_{\mathrm{T}}$ with depth, which we believe is due to rapid mixing between intermediate and deep waters and the short residence time of the water masses (Yoon et al., 1999).

Station $17 \mathrm{~N}$ showed relatively high $\mathrm{Chl} a$ concentration at depth of Chl $a$ maximum with no variation in $\delta^{65} \mathrm{Cu}$. Remineralisation or desorption of $\mathrm{Cu}$ from particulate matter with consequent release of light $\mathrm{Cu}$ to the dissolved pool could have competed with the biological activity at this station. Remineralization was reported to be limited in the Mediterranean Sea (Dulaquais et al., 2017), however, we do not exclude an external source of particulate $\mathrm{Cu}$ (e.g. continental run-off, coastal sediments release) as a more substantial source of isotopically light $\mathrm{dCu}$ to the dissolved phase at this station.

\subsubsection{Variations of $\mathrm{Cu}$ and $\delta^{65} \mathrm{Cu}$ at benthic depth.}

Bottom depth increases in $\mathrm{dCu}$ have been reported in the open Ocean and interpreted as the result of the recycling of scavenged $\mathrm{Cu}$ during early diagenesis and supply to the overlying seawater (Boyle et al., 1977; Bruland, 1980; Saager et al., 1997). At benthic depths, a significant increase in $[\mathrm{dCu}]_{\mathrm{T}}$ was accompanied by concomitant decline in $\delta^{65} \mathrm{Cu}$ at stations 3 , 
$11 \mathrm{~S}$, and $9 \mathrm{~N}$ and $17 \mathrm{~N}$. A concomitant decrease in $\delta^{65} \mathrm{Cu}$ at the sedimentary interface was also observed for North Pacific and Tasmanian stations (Takano et al., 2014; Thompson et al., 2013). Using a simple mixing model, we calculated for the aforementioned stations the $\delta^{65} \mathrm{Cu}$ value of the sediment source, which varied between $-0.2 \%$ and $+0.5 \%$ for a contribution of sedimentary $\mathrm{Cu}$ to the dissolved pool ranging from $10 \%$ to $50 \%$. Details of the equation and results are available in the supplementary material as Supplementary equation 1 and Supplementary table 1 . The calculated range in isotopic composition of the sediment source at these stations encompasses that of $\delta^{65} \mathrm{Cu}$ in authigenic and lithogenic sediments (Little et al., 2017).

In the Mediterranean Sea, particulate export of $\mathrm{Cu}$ to the sediment is mostly associated with organic matter (Cossa et al., 2014; Heimbürger et al., 2014; Migon, 2005; Sakellari et al., 2011), and the release of $\mathrm{Cu}$ by aerobic organic matter degradation into sediment pore waters (Shaw et al., 1990) is likely linked to the release of isotopically-light $\mathrm{Cu}$. This observation is further supported by sediment-resuspension experiments, which showed that $\mathrm{dCu}$ in pore water originates mostly from particulate organic matter degradation and that complexation of $\mathrm{Cu}$ with dissolved organic matter in seawater stabilizes the element in solution after resuspension of the sediments (Gerringa, 1990; Saulnier, 1997). The low $\delta^{65} \mathrm{Cu}$ value of $+0.33 \%$ found at $400 \mathrm{~m}$ at station 4 could therefore be explained by sediment resuspension caused by the flow of MSOW over the Gibraltar sill. In a similar way, station $5 \mathrm{~N}$ showed a significant decrease of $\delta^{65} \mathrm{Cu}$ at $3250 \mathrm{~m}$. Adriatic bottom water flows at benthic depth from the shallow Adriatic Sea to the deep Ionian Sea where station 5S is located (Van Aken, 2015), and might be transporting $\mathrm{dCu}$ released from sediment over the sharp slope of the South Adriatic Pit. 


\section{Conclusion}

We developed and applied a new technique for the determination of $\delta^{65} \mathrm{Cu}$ in seawater and reported variations in $\mathrm{Cu}$ concentration and isotope ratio for 12 stations in the Mediterranean Sea and Atlantic Ocean. The method accuracy was successfully tested through experiments and we obtained an overall analytical precision of $0.06 \% 2$ s.d. Disparities in $\delta^{65} \mathrm{Cu}$ between studies on GEOTRACES inter-comparison samples from the Bermuda station BATS show that there is a need for collaboration between laboratories in order to develop a new intercomparison sample and determine how crucial the use of $\mathrm{UV}$-oxidation is in $\mathrm{dCu}$ isotopes analysis.

Using the extensive dataset for $\delta^{65} \mathrm{Cu}$ and $[\mathrm{dCu}]_{\mathrm{T}}$ generated in this study, we were able to observe variations mostly occurring within the euphotic zone ( $0-200 \mathrm{~m}$ ) and at benthic depths. We suggest these variations result from a combination of addition of $\mathrm{Cu}$ from various sources feeding the basins, physical mixing and biological activity. Copper concentration measurements coupled with atmospheric back-tracking modeling showed a clear zonation between mineral dust deposition from the Saharan desert at the Southern Mediterranean stations vs. anthropogenic aerosol deposition from the populated and industrialized Western Europe at the Northern Mediterranean stations. Saharan dust deposition appears to be a source of isotopically light $\mathrm{Cu}$ to the Southern stations, and because dissolution rate of natural dust deposits are low, this effect appears to be seen deeper in the euphotic zone. In contrast, anthropogenic/combustion-related aerosols have a high solubility and carry $\delta^{65} \mathrm{Cu}$ isotopically heavier than mineral dust sources, and their impact on the Northern stations appears to be at shallower depths and limited to variations in $[\mathrm{dCu}]_{\mathrm{T}}$. The possible role of the Iberian Pyrite Belt as a source of isotopically-heavy $\mathrm{dCu}$ to the Mediterranean Sea was also highlighted, but further study needs to address the $\delta^{65} \mathrm{Cu}$ of dissolved and particulate phases in the Rio Tinto and Odiel rivers. We also observed a significant increase in $\delta^{65} \mathrm{Cu}$ within the 
Chl a maximum likely due to uptake and/or scavenging of isotopically light $\mathrm{dCu}$ in or onto phytoplankton. Finally, at bottom depths, sediments appear to be a source of isotopically light $\mathrm{dCu}$ from pore waters via resuspension.

Future studies should focus on the fractionation between dissolved, organically-complexed and particulate fractions of $\mathrm{Cu}$ to better apprehend the processes driving $\mathrm{Cu}$ biogeochemical cycling in seawater. A better understanding of the variations of $\delta^{65} \mathrm{Cu}$ in seawater would allow the use of $\delta^{65} \mathrm{Cu}$ as a tool to better evaluate the origin of the missing import and export fluxes of $\mathrm{dCu}$ in the marine realm, and the impact of anthropogenic sources on the Ocean.

\section{Acknowledgments}

We first and foremost would like to thank three anonymous reviewers and Susan Little for their critical comments which proved decisive in the making of this paper. We thank Emmanuel Ponzevera for daily maintenance of the MC-ICPMS at the Pole Spectrometrie Ocean (Brest) and Yoan Germain for laboratory assistance. Support for this study was provided by the Institut Carnot Ifremer EDROME, the LabexMer ANR-10-LABX-19-01, Europole Mer and FP7 (\#247837) grant. We thank the crew of the RV Pelagia and chief scientist Micha Rijkenberg for their support and input during cruise operations \#64PE370 and \#64PE374. The authors also gratefully acknowledge the NOAA Air Resources Laboratory (ARL) for the provision of the HYSPLIT transport and dispersion model and/or READY website (http://www.ready.noaa.gov) used in this publication.

\section{References}

Albarede, F., 2004. The stable isotope geochemistry of copper and zinc. Reviews in mineralogy and geochemistry, 55(1): 406-427.

Ambar, I., Howe, M.R., 1979. Observations of the Mediterranean outflow .2. Deep circulation in the vicinity of the Gulf of Cadiz. Deep-Sea Research Part aOceanographic Research Papers, 26(5): 555-568.

Archer, C., Vance, D., 2004. Mass discrimination correction in multiple-collector plasma source mass spectrometry: an example using $\mathrm{Cu}$ and $\mathrm{Zn}$ isotopes. Journal of Analytical Atomic Spectrometry, 19(5): 656-665. 
Arndt, J. et al., 2017. Sources and mixing state of summertime background aerosol in the north-western Mediterranean basin. Atmospheric Chemistry and Physics, 17(11): 6975-7001.

Babcsanyi, I. et al., 2016. Copper in soil fractions and runoff in a vineyard catchment: Insights from copper stable isotopes. Science of the Total Environment, 557: 154-162.

Babcsanyi, I., Imfeld, G., Granet, M., Chabaux, F., 2014. Copper Stable Isotopes To Trace Copper Behavior in Wetland Systems. Environmental Science \& Technology, 48(10): 5520-5529.

Bermin, J., Vance, D., Archer, C., Statham, P.J., 2006. The determination of the isotopic composition of $\mathrm{Cu}$ and $\mathrm{Zn}$ in seawater. Chemical Geology, 226(3-4): 280-297.

Bethoux, J.P., 1980. Mean water fluxes across sections in the Mediterranean-Sea, evaluated on the basis of water and salt budgets and of observed salinities. Oceanologica Acta, 3(1): 79-88.

Bigalke, M., Weyer, S., Wilcke, W., 2010. Copper Isotope Fractionation during Complexation with Insolubilized Humic Acid. Environmental Science \& Technology, 44(14): 5496-5502.

Bigalke, M., Weyer, S., Wilcke, W., 2011. Stable $\mathrm{Cu}$ isotope fractionation in soils during oxic weathering and podzolization. Geochimica Et Cosmochimica Acta, 75(11): 3119-3134.

Biller, D.V., Bruland, K.W., 2012. Analysis of $\mathrm{Mn}, \mathrm{Fe}, \mathrm{Co}, \mathrm{Ni}, \mathrm{Cu}, \mathrm{Zn}, \mathrm{Cd}$, and $\mathrm{Pb}$ in seawater using the Nobias-chelate PA1 resin and magnetic sector inductively coupled plasma mass spectrometry (ICP-MS). Marine Chemistry, 130: 12-20.

Borrok, D.M., Nimick, D.A., Wanty, R.B., Ridley, W.I., 2008. Isotopic variations of dissolved copper and zinc in stream waters affected by historical mining. Geochimica et Cosmochimica Acta, 72(2): 329-344.

Borrok, D.M. et al., 2007. Separation of copper, iron, and zinc from complex aqueous solutions for isotopic measurement. Chemical Geology, 242(3-4): 400-414.

Boyle, E.A., Chapnick, S.D., Bai, X.X., Spivack, A., 1985. Trace-metal enrichments in the Mediterranean-Sea. Earth and Planetary Science Letters, 74(4): 405-419.

Boyle, E.A. et al., 2012. GEOTRACES IC1 (BATS) contamination-prone trace element isotopes $\mathrm{Cd}, \mathrm{Fe}, \mathrm{Pb}, \mathrm{Zn}, \mathrm{Cu}$, and Mo intercalibration. Limnology and OceanographyMethods, 10: 653-665.

Boyle, E.A., Sclater, F.R., Edmond, J.M., 1977. The distribution of dissolved copper in the Pacific. Earth and Planetary Science Letters, 37(1): 38-54.

Bruland, K.W., 1980. Oceanographic distributions of cadmium, zinc, nickel, and copper in the North Pacific. Earth and Planetary Science Letters, 47(2): 176-198.

Bruland, K.W., Franks, R.P., 1983. Mn, Ni, Cu, Zn and Cd in the Western North Atlantic, Trace Metals in Sea Water. NATO Conference Series. Springer US, pp. 395-414.

Coale, K.H., Bruland, K.W., 1988. Copper complexation in the Northeast Pacific. Limnology and Oceanography, 33(5): 1084-1101.

Coale, K.H. et al., 1996. A massive phytoplankton bloom induced by an ecosystem-scale iron fertilization experiment in the equatorial Pacific Ocean. Nature, 383(6600): 495-501.

Cossa, D. et al., 2014. Origin and accumulation of trace elements in sediments of the northwestern Mediterranean margin. Chemical Geology, 380: 61-73.

Coste, B., Lecorre, P., Minas, H.J., 1988. Reevaluation of the nutrient exchanges in the Strait of Gibraltar. Deep-Sea Research Part a-Oceanographic Research Papers, 35(5): 767775.

Croot, P.L., Moffett, J.W., Brand, L.E., 2000. Production of extracellular $\mathrm{Cu}$ complexing ligands by eucaryotic phytoplankton in response to $\mathrm{Cu}$ stress. Limnology and Oceanography, 45(3): 619-627. 
Cutter, C. et al., 2014. Sampling and Sample-handling Protocols for GEOTRACES Cruises (version 2.0). In: www.geotraces.org/ (Editor).

De Baar, H.J.W. et al., 2008. Titan: A new facility for ultraclean sampling of trace elements and isotopes in the deep oceans in the international Geotraces program. Marine Chemistry, 111(1-2): 4-21.

Desboeufs, K.V., Sofikitis, A., Losno, R., Colin, J.L., Ausset, P., 2005. Dissolution and solubility of trace metals from natural and anthropogenic aerosol particulate matter. Chemosphere, 58(2): 195-203.

Dong, S.F. et al., 2013. Stable isotope ratio measurements of $\mathrm{Cu}$ and $\mathrm{Zn}$ in mineral dust (bulk and size fractions) from the Taklimakan Desert and the Sahel and in aerosols from the eastern tropical North Atlantic Ocean. Talanta, 114: 103-109.

Duce, R.A., Tindale, N.W., 1991. Atmospheric transport of Iron and its deposition in the ocean. Limnology and Oceanography, 36(8): 1715-1726.

Dulaquais, G., Planquette, H., L'Helguen, S., Rijkenberg, M.J.A., Boye, M., 2017. The biogeochemistry of cobalt in the Mediterranean Sea. Global Biogeochemical Cycles, 31(2): 377-399.

Ehrlich, S. et al., 2004. Experimental study of the copper isotope fractionation between aqueous $\mathrm{Cu}(\mathrm{II})$ and covellite, $\mathrm{CuS}$. Chemical Geology, 209: 259- 269.

Elbaz-Poulichet, F., Morley, N.H., Beckers, J.M., Nomerange, P., 2001. Metal fluxes through the Strait of Gibraltar: the influence of the Tinto and Odiel rivers (SW Spain). Marine Chemistry, 73(3-4): 193-213.

Elbaz-Poulichet, F. et al., 1999. Trace metal and nutrient distribution in an extremely low $\mathrm{pH}(2.5)$ river-estuarine system, the Ria of Huelva (South-West Spain). Science of the Total Environment, 227(1): 73-83.

Fujii, T., Moynier, F., Abe, M., Nemoto, K., Albarède, F., 2013. Copper isotope fractionation between aqueous compounds relevant to low temperature geochemistry and biology. Geochimica et Cosmochimica Acta, 110: 29-44.

Gascard, J.C., Richez, C., 1985. Water masses and circulation in the Western Alboran Sea and in the Straits of Gibraltar. Progress in Oceanography, 15(3): 157-216.

Gerringa, L.J.A., 1990. Aerobic degradation of organic matter and the mobility of $\mathrm{Cu}, \mathrm{Cd}, \mathrm{Ni}$, $\mathrm{Pb}, \mathrm{Zn}, \mathrm{Fe}$ and $\mathrm{Mn}$ in marine sediment slurries. Marine Chemistry, 29(4): 355-374.

Gerringa, L.J.A. et al., 2017. Dissolved $\mathrm{Fe}$ and $\mathrm{Fe}$-binding organic ligands in the Mediterranean Sea GEOTRACES G04. Marine Chemistry, 194: 100-113.

Gonzalez, R.O. et al., 2016. New Insights from Zinc and Copper Isotopic Compositions into the Sources of Atmospheric Particulate Matter from Two Major European Cities. Environmental Science and Technology, 50(18): 9816-9824.

Goudie, A.S., Middleton, N.J., 2001. Saharan dust storms: nature and consequences. EarthScience Reviews, 56(1-4): 179-204.

Graham, S., Pearson, N., Jackson, S., Griffin, W., O'reilly, S.Y., 2004. Tracing Cu and Fe from source to porphyry: in situ determination of $\mathrm{Cu}$ and Fe isotope ratios in sulfides from the Grasberg $\mathrm{Cu}-\mathrm{Au}$ deposit. Chemical Geology, 207(3-4): 147-169.

Guerzoni, S. et al., 1999. The role of atmospheric deposition in the biogeochemistry of the Mediterranean Sea. Progress in Oceanography, 44(Issues 1-3): 147-190.

Guieu, C., Martin, J.M., Thomas, A.J., Elbazpoulichet, F., 1991. Atmospheric versus river inputs of metals to the Gulf of Lions - Total concentrations, partitioning and fluxes. Marine Pollution Bulletin, 22(4): 176-183.

Heimbürger, L.E. et al., 2014. Vertical export flux of metals in the Mediterranean Sea. Deep Sea Research Part I: Oceanographic Research Papers, 87: 14-23. 
Herut, B. et al., 2005. Response of East Mediterranean surface water to Saharan dust: Onboard microcosm experiment and field observations. Deep-Sea Research Part IITopical Studies in Oceanography, 52(22-23): 3024-3040.

Howe, M.R., 1982. The Mediterranean water outflow in the Gulf of Cadiz. Oceanography and Marine Biology, 20: 37-64.

Hsu, S.C., Lin, F.J., Jeng, W.L., 2005. Seawater solubility of natural and anthropogenic metals within ambient aerosols collected from Taiwan coastal sites. Atmospheric Environment, 39(22): 3989-4001.

Jacquot, J.E., Moffett, J.W., 2015. Copper distribution and speciation across the International GEOTRACES Section GA03. Deep Sea Research Part II: Topical Studies in Oceanography, 116: 187-207.

Jordi, A., Basterretxea, G., Tovar-Sanchez, A., Alastuey, A., Querol, X., 2012. Copper aerosols inhibit phytoplankton growth in the Mediterranean Sea. Proceedings of the National Academy of Sciences of the United States of America, 109(52): 2124621249.

Kimball, B.E. et al., 2009. Copper isotope fractionation in acid mine drainage. Geochimica Et Cosmochimica Acta, 73(5): 1247-1263.

Larson, P.B. et al., 2003. Copper isotope ratios in magmatic and hydrothermal ore-forming environments. Chemical Geology, 201(3-4): 337-350.

Laubier, L., 2005. Mediterranean Sea and Humans: improving a conflictual partnership. In: Saliot, A. (Ed.), The Mediterranean Sea. The Handbook of Environmental Chemistry. Springer-Verlag Berlin Heidelberg, pp. 3-27.

Laumond, F., Copinmontegut, G., Courau, P., Nicolas, E., 1984. Cadmium, copper and lead in the Western Mediterranean Sea. Marine Chemistry, 15(3): 251-261.

Little, S.H. et al., 2018. Paired dissolved and particulate phase $\mathrm{Cu}$ isotope distributions in the South Atlantic. Chemical Geology.

Little, S.H., Vance, D., McManus, J., Severmann, S., Lyons, T.W., 2017. Copper isotope signatures in modern marine sediments. Geochimica Et Cosmochimica Acta, 212: 253-273.

Little, S.H., Vance, D., Siddall, M., Gasson, E., 2013. A modeling assessment of the role of reversible scavenging in controlling oceanic dissolved $\mathrm{Cu}$ and $\mathrm{Zn}$ distributions. Global Biogeochemical Cycles, 27(3): 780-791.

Little, S.H., Vance, D., Walker-brown, C., Landing, W.M., 2014. The oceanic mass balance of copper and zinc isotopes, investigated by analysis of their inputs, and outputs to ferromanganese oxide sediments. Geochimica et Cosmochimica Acta(125): 673-693.

Lohan, M.C., Aguilar-Islas, A.M., Franks, R.P., Bruland, K.W., 2005. Determination of iron and copper in seawater at $\mathrm{pH} 1.7$ with a new commercially available chelating resin, NTA Superflow. Analytica Chimica Acta, 530(1): 121-129.

Ludwig, W., Dumont, E., Meybeck, M., Heussner, S., 2009. River discharges of water and nutrients to the Mediterranean and Black Sea: Major drivers for ecosystem changes during past and future decades? Progress in Oceanography, 80(3-4): 199-217.

Mackey, K.R.M., Chien, C.T., Post, A.F., Saito, M.A., Paytan, A., 2014. Rapid and gradual modes of aerosol trace metal dissolution in seawater. Frontiers in Microbiology, 5(794).

Maher, K.C., Larson, P.B., 2007. Variation in Copper Isotope Ratios and Controls on Fractionation in Hypogene Skarn Mineralization at Coroccohuayco and Tintaya, Perú. Economic Geology, 102: 225-237.

Mallet, M. et al., 2016. Overview of the Chemistry-Aerosol Mediterranean Experiment/Aerosol Direct Radiative Forcing on the Mediterranean Climate 
(ChArMEx/ADRIMED) summer 2013 campaign. Atmospheric Chemistry and Physics, 16(2): 455-504.

Marechal, C.N., Telouk, P., Albarede, F., 1999. Precise analysis of copper and zinc isotopic compositions by plasma-source mass spectrometry. Chemical Geology, 156(1-4): 251-273.

Mariotti, A., Struglia, M.V., Zeng, N., Lau, K.M., 2002. The hydrological cycle in the Mediterranean region and implications for the water budget of the Mediterranean Sea. Journal of Climate, 15(13): 1674-1690.

Mason, T.F.D. et al., 2005. $\mathrm{Zn}$ and $\mathrm{Cu}$ isotopic variability in the Alexandrinka volcanichosted massive sulphide (VHMS) ore deposit, Urals, Russia. Chemical Geology, 221: 170-187.

Mason, T.F.D. et al., 2004. High-precision $\mathrm{Cu}$ and $\mathrm{Zn}$ isotope analysis by plasma source mass spectrometry - Part 1. Spectral interferences and their correction. Journal of Analytical Atomic Spectrometry, 19(2): 209-217.

Mathur, R. et al., 2005. Cu isotopic fractionation in the supergene environment with and without bacteria. Geochimica et Cosmochimica Acta, 69: 5233-5246.

May, T.W., Wiedmeyer, R.H., 1998. A table of polyatomic interferences in ICP-MS. Atomic Spectroscopy, 19(5): 150-155.

McDougall, T.J., Barker, P.M., 2011. Getting started with the TEOS-10 and the Gibbs Seawater (GSW) Oceanographic Toolbox. In: WG127, S.I. (Editor).

Middag, R. et al., 2015. Intercomparison of dissolved trace elements at the Bermuda Atlantic Time Series station. Marine Chemistry, 177(3): 476-489.

Migon, C., 2005. Trace metals in the Mediterranean Sea. In: Saliot, A. (Ed.), The Mediterranean Sea. The Handbook of environmental chemistry. Berlin-Heidelberg Springer-Verlag, pp. 151-176.

Millot, C., Taupier-Letage, I., 2005. Circulation in the Mediterranean sea. In: Saliot, A. (Ed.), The Mediterranean Sea. The Handbook of Environmental Chemistry. Springer Verlag Berlin-Heidelberg, pp. 29-66.

Milne, A., Landing, W., Bizimis, M., Morton, P., 2010. Determination of Mn, Fe, Co, Ni, Cu, $\mathrm{Zn}, \mathrm{Cd}$ and $\mathrm{Pb}$ in seawater using high resolution magnetic sector inductively coupled mass spectrometry (HR-ICP-MS). Analytica Chimica Acta, 665(2): 200-207.

Moeller, K., Schoenberg, R., Pedersen, R.-B., Weiss, D., Dong, S., 2012. Calibration of the New Certified Reference Materials ERM-AE633 and ERM-AE647 for Copper and IRMM-3702 for Zinc Isotope Amount Ratio Determinations. Geostandards and Geoanalytical Research, 36(2): 177-199.

Moffett, J.W., Brand, L.E., 1996. Production of strong, extracellular Cu chelators by marine cyanobacteria in response to $\mathrm{Cu}$ stress. Limnology and Oceanography, 41(3): 388395.

Moffett, J.W., Brand, L.E., Croot, P.L., Barbeau, K.A., 1997. Cu speciation and cyanobacterial distribution in harbors subject to anthropogenic $\mathrm{Cu}$ inputs. Limnology and Oceanography, 42(5): 789-799.

Moffett, J.W., Dupont, C., 2007. Cu complexation by organic ligands in the sub-arctic NW Pacific and Bering Sea. Deep-Sea Research Part I-Oceanographic Research Papers, 54(4): 586-595.

Moffett, J.W., Zika, R.G., Brand, L.E., 1990. Distribution and potential sources and sinks of copper chelators in the Sargasso Sea. Deep-Sea Research Part a-Oceanographic Research Papers, 37(1): 27-36.

Morley, N.H., Burton, J.D., Tankere, S.P.C., Martin, J.M., 1997. Distribution and behaviour of some dissolved trace metals in the western Mediterranean Sea. Deep-Sea Research Part II-Topical Studies in Oceanography, 44(3-4): 675-691. 
Moynier, F., Vance, D., Fujii, T., Savage, P., 2017. The Isotope Geochemistry of Zinc and Copper. In: Teng, F.Z., Watkins, J., Dauphas, N. (Eds.), Non-Traditional Stable Isotopes. Reviews in Mineralogy \& Geochemistry. Mineralogical Society of America \& Geochemical Society, Chantilly, pp. 543-600.

Navarrete, J.U., Borrok, D.M., Viveros, M., Ellzey, J.T., 2011. Copper isotope fractionation during surface adsorption and intracellular incorporation by bacteria. Geochimica Et Cosmochimica Acta, 75(3): 784-799.

Nelson, C.H., Lamothe, P.J., 1993. Heavy-metal anomalies in the Tinto and Odiel river and estuary system, Spain. Estuaries, 16(3A): 496-511.

Peers, G., Price, N.M., 2006. Copper-containing plastocyanin used for electron transport by an oceanic diatom. Nature, 441(7091): 341-344.

Peers, G., Quesnel, S.A., Price, N.M., 2005. Copper requirements for iron acquisition and growth of coastal and oceanic diatoms. Limnology and Oceanography, 50(4): 11491158.

Pistocchi, R., Mormile, M.A., Guerrini, F., Isani, G., Boni, L., 2000. Increased production of extra- and intracellular metal-ligands in phytoplankton exposed to copper and cadmium | SpringerLink. Journal of Applied Phycology, 12(3-5): 469-477.

Pokrovsky, O.S., Viers, J., Emnova, E.E., Kompantseva, E.I., Freydier, R., 2008. Copper isotope fractionation during its interaction with soil and aquatic microorganisms and metal oxy(hydr)oxides: Possible structural control. Geochimica et Cosmochimica Acta, 72: 1742-1757.

Posacka, A.M. et al., 2017. Dissolved copper (dCu) biogeochemical cycling in the subarctic Northeast Pacific and a call for improving methodologies. Marine Chemistry(196): 47-61.

Richardson, P.L., Bower, A.S., Zenk, W., 2000. A census of Meddies tracked by floats. Progress in Oceanography, 45(2): 209-250.

Rijkenberg, M.J.A., 2013a. MedBlack GEOTRACES leg 1, cruise report 64PE370 on RV Pelagia, 14 May - 5 June 2013.

Rijkenberg, M.J.A., 2013b. MedBlack GEOTRACES leg 3, cruise report 64PE374 on RV Pelagia, 25 July - 11 August 2013.

Robinson, A.R., Leslie, W.G., Theocharis, A., Lascaratos, A., 2001. Mediterranean sea circulation. In: Steele, J.H., Thorpe , S.A., Turekian, K.K. (Eds.), Ocean currents: a derivative of the Encyclopedia of Ocean Sciences. Academic Press, pp. 1689-1705.

Robinson, A.R. et al., 1992. General circulation of the Eastern Mediterranean. Earth-Science Reviews, 32(4): 285-309.

Rolison, J.M., Middag, R., Stirling, C.H., Rijkenberg, M.J.A., de Baar, H.J.W., 2015. Zonal distribution of dissolved aluminium in the Mediterranean Sea. Marine Chemistry, 177: 87-100.

Rolph, G., Stein, A., Stunder, B., 2015. Real-time Environmental Applications and Display sYstem: READY. Environmental Modelling \& Software, 95: 210-228.

Roshan, S., Wu, J.F., 2015. The distribution of dissolved copper in the tropical-subtropical north Atlantic across the GEOTRACES GA03 transect. Marine Chemistry, 176: 189198.

Rossini, P. et al., 2001. Atmospheric deposition of trace metals in North Adriatic Sea, Mediterranean Ecosystems: Structures and Processes. Springer, Milano, pp. 123-129.

Rouxel, O., Fouquet, Y., Ludden, J.N., 2004. Copper Isotope systematics of the Lucky Strike, Rainbow and Logatchev Seafloor Hydrothermal Fields on the Mid Atlantic Ridge. Econ. Geol., 99: 585-600.

Rouxel, O.J., Auro, M., 2010. Iron Isotope Variations in Coastal Seawater Determined by Multicollector ICP-MS. Geostandards and Geoanalytical Research, 34(2): 135-144. 
Rue, E., Bruland, K., 2001. Domoic acid binds iron and copper: a possible role for the toxin produced by the marine diatom Pseudo-nitzschia. Marine Chemistry, 76(1-2): 127134.

Ryan, B.M., Kirby, J.K., Degryse, F., Scheiderich, K., McLaughlin, M.J., 2014. Copper Isotope Fractionation during Equilibration with Natural and Synthetic Ligands. Environmental Science \& Technology, 48(15): 8620-8626.

Saager, P.M., De Baar, H.J.W., R.J., H., 1992. Cd, Zn, Ni and Cu in the Indian Ocean. Deep Sea Research Part A. Oceanographic Research Papers, 39(1): 9-35.

Saager, P.M., deBaar, H.J.W., deJong, J.T.M., Nolting, R.F., Schijf, J., 1997. Hydrography and local sources of dissolved trace metals $\mathrm{Mn}, \mathrm{Ni}, \mathrm{Cu}$, and $\mathrm{Cd}$ in the northeast Atlantic Ocean. Marine Chemistry, 57(3-4): 195-216.

Saager, P.M., Schijf, J., De Baar, H.J.W., 1993. Trace-metal distributions in seawater and anoxic brines in the Eastern Mediterranean Sea. Geochimica et Cosmochimica Acta, 57(7): 1419-1432.

Sakellari, A., Plavsic, M., Karavoltsos, S., Dassenakis, M., Scoullos, M., 2011. Assessment of copper, cadmium and zinc remobilization in Mediterranean marine coastal sediments. Estuarine Coastal and Shelf Science, 91(1): 1-12.

Saulnier, I., 1997. Trace metal remobilization following the resuspension of Saguenay Fjord sediments, McGill University, Montreal, Quebec, Canada.

Schlitzer, R., 2016. Ocean Data View, http://odv.awi.de.

Schreiber, D.R., Millero, F.J., Gordon, A.S., 1990. Production of an extracellular copperbinding compound by the heterotrophic marine bacterium Vibrio alginolyticus. Marine Chemistry, 28(4): 275-284.

Semeniuk, D.M., Bundy, R.M., Payne, C.D., Barbeau, K.A., Maldonado, M.T., 2015. Acquisition of organically complexed copper by marine phytoplankton and bacteria in the northeast subarctic Pacific Ocean. Marine Chemistry, 173: 222-233.

Semeniuk, D.M. et al., 2009. Plankton copper requirements and uptake in the subarctic Northeast Pacific Ocean. Deep Sea Research Part I: Oceanographic Research Papers, 56(7): 1130-1142.

Send, U. et al., 1999. Recent advances in observing the physical oceanography of the western Mediterranean Sea. Progress in Oceanography, 44(1-3): 37-64.

Shaw, T.J., Gieskes, J.M., Jahnke, R.A., 1990. Early diagenesis in differing depositional environments - The response of transition metals in pore water. Geochimica Et Cosmochimica Acta, 54(5): 1233-1246.

Sherman, D.M., 2013. Equilibrium isotopic fractionation of copper during oxidation/reduction, aqueous complexation and ore-forming processes: Predictions from hybrid density functional theory. Geochimica Et Cosmochimica Acta, 118: 8597.

Sholkovitz, E.R., Sedwick, P.N., Church, T.M., 2010. On the fractional solubility of copper in marine aerosols: Toxicity of aeolian copper revisited. Geophysical Research Letters, 37: 4.

Stein, A.F. et al., 2015. NOAA's HYSPLIT atmospheric transport and dispersion modeling system. Bulletin of American Meteorological Society, 96: 2059-2077.

Takano, S., Tanimizu, M., Hirata, T., Sohrin, Y., 2013. Determination of isotopic composition of dissolved copper in seawater by multi-collector inductively coupled plasma mass spectrometry after pre-concentration using an ethylenediaminetriacetic acid chelating resin. Analytica chimica acta, 784.

Takano, S., Tanimizu, M., Hirata, T., Sohrin, Y., 2014. Isotopic constraints on biogeochemical cycling of copper in the ocean. Nature Communications, 5: 7. 
Tankere, S.P.C., Statham, P.J., 1996. Distribution of dissolved Cd, Cu, Ni and Zn in the Adriatic Sea. Marine Pollution Bulletin, 32(8-9): 623-630.

Ternon, E., Guieu, C., Ridame, C., L'Helguen, S., Catala, P., 2011. Longitudinal variability of the biogeochemical role of Mediterranean aerosols in the Mediterranean Sea. Biogeosciences, 8(5): 1067-1080.

Thompson, C.M., Ellwood, M.J., 2014. Dissolved copper isotope biogeochemistry in the Tasman Sea, SW Pacific Ocean. Marine Chemistry, 165: 1-9.

Thompson, C.M., Ellwood, M.J., Wille, M., 2013. A solvent extraction technique for the isotopic measurement of dissolved copper in seawater. Analytica Chimica Acta, 775: 106-113.

Van Aken, H.M., 2015. The hydrography encountered during the GEOTRACES/MedBlack programme (2013).

Van Geen, A., Adkins, J.F., Boyle, E.A., Nelson, C.H., Palanques, A., 1997. A 120-yr record of widespread contamination from mining of the Iberian pyrite belt. Geology, 25.

Van Geen, A., Boyle, E., 1990. Variability of trace-metal fluxes through the Strait of Gibraltar. Palaeogeography, Palaeoclimatology, Palaeoecology, 89: 65-75.

Van Geen, A., Rosener, P., Boyle, E., 1988. Entrainment of trace-metal-enriched Atlanticshelf water in the inflow to the Mediterranean-Sea. Nature, 331(6155): 423-426.

Van Geen, A.F.M.J., 1989. Trace metal sources for the Atlantic inflow to the Mediterranean Sea. Thesis Thesis, Massachusetts Institute of Technology, Massachussetts Institute of Technology, $179 \mathrm{pp}$.

Vance, D. et al., 2008. The copper isotope geochemistry of rivers and the oceans. Earth and Planetary Science Letters, 274: 204-213.

Wall, A.J., Heaney, P.J., Mathur, R., Post, J.E., 2007. Insights into copper isotope fractionation during the oxidative phase transition of chalcocite, using time-resolved synchrotron X-ray diffraction. Geochimica Et Cosmochimica Acta, 71(15): A1081A1081.

Yoon, Y.-Y., Martin, J.-M., Cottéc, M.H., 1999. Dissolved trace metals in the Western Mediterranean Sea: total concentration and fraction isolated by C18 Sep-Pak technique. Marine Chemistry, 66(Issues 3-4): 129-148.

Zago, C. et al., 2002. Heavy metal distribution and speciation in the Northern Adriatic Sea. Chemistry and Ecology, 18(1-2): 39-51.

Zenk, W., Armi, L., 1990. The complex spreading pattern of Mediterranean water off the Portuguese continental-slope. Deep-Sea Research Part a-Oceanographic Research Papers, 37(12): 1805-1823.

Zhu, X.K. et al., 2002. Mass fractionation processes of transition metal isotopes. Earth Planet. Sci. Lett., 200: 47-62.

Zhu, X.K., O'Nions, R.K., Guo, Y., Belshaw, N.S., Rickard, D., 2000. Determination of natural $\mathrm{Cu}$-isotope variation by plasma-source mass spectrometry: implications for use as geochemical tracers. Chemical Geology, 163(1-4): 139-149.

Zumft, W.G., Kroneck, P.M.H., 2007. Respiratory transformation of nitrous oxide (N(2)O) to dinitrogen by Bacteria and Archaea. In: Poole, R.K. (Ed.), Advances in Microbial Physiology, Vol 52. Advances in Microbial Physiology. Academic Press Ltd-Elsevier Science Ltd, London, pp. 107-+. 


\section{Figures and Figure captions}

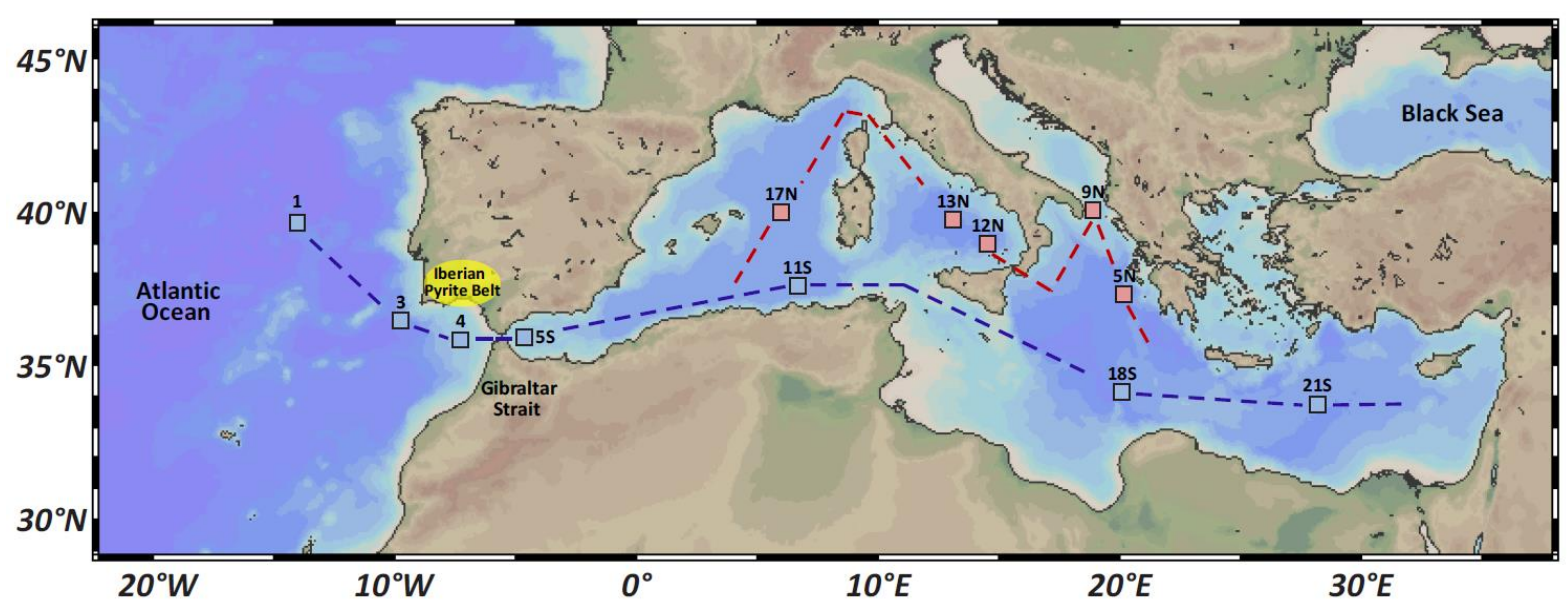

Figure 1: Location of the seawater stations sampled in the Mediterranean Sea and Atlantic Ocean. The blue dashed line represents part of the southern route of the cruise, going from Atlantic to South-East Mediterranean Sea. The red dashed line represents portion of the northern route, going from North-East Mediterranean Sea to North-West Mediterranean Sea.

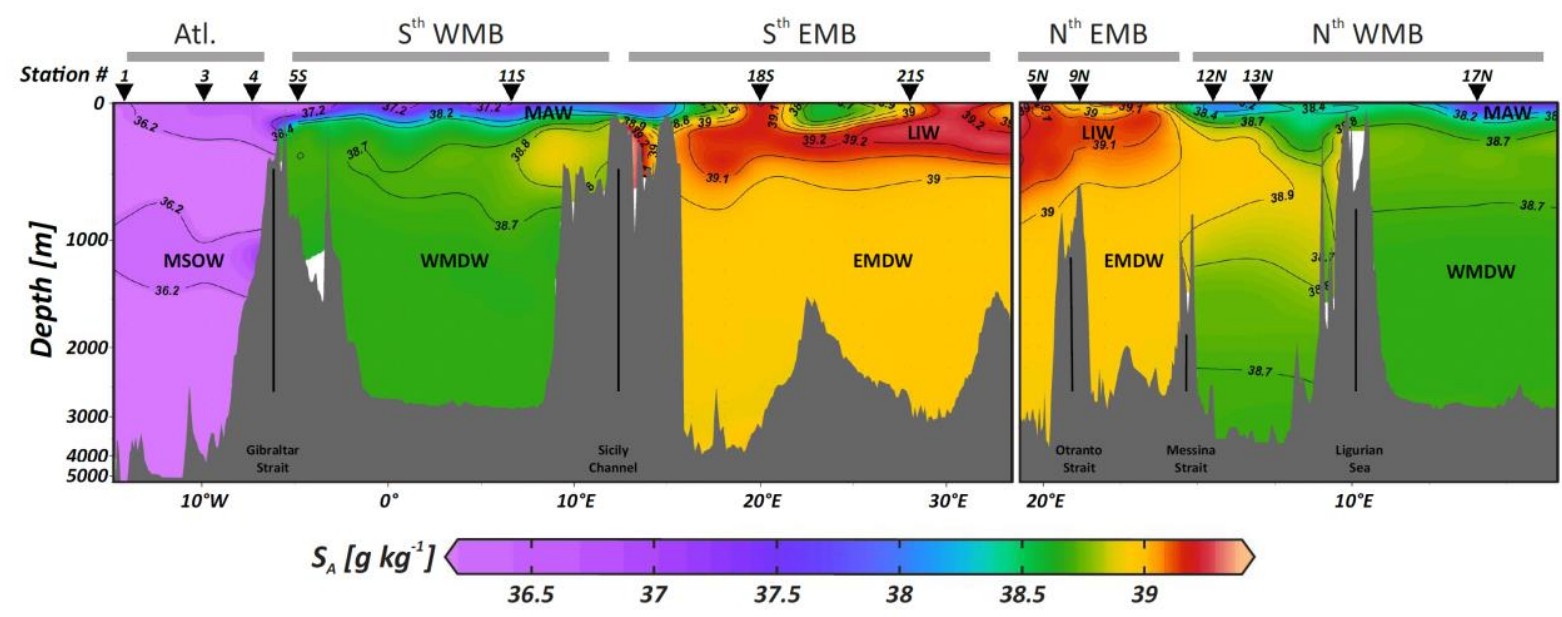

Figure 2: Absolute salinity $\left(\mathrm{S}_{\mathrm{A}}\right)$ along the transects shown in Fig. 1. Water masses are labelled as: MAW (Modified Atlantic Water), MSOW (Mediterranean Sea Outflow Water), WMDW (Western Deep Mediterranean Water), EMDW (Eastern Mediterranean Deep Water), LIW (Levantine Intermediate Water). 


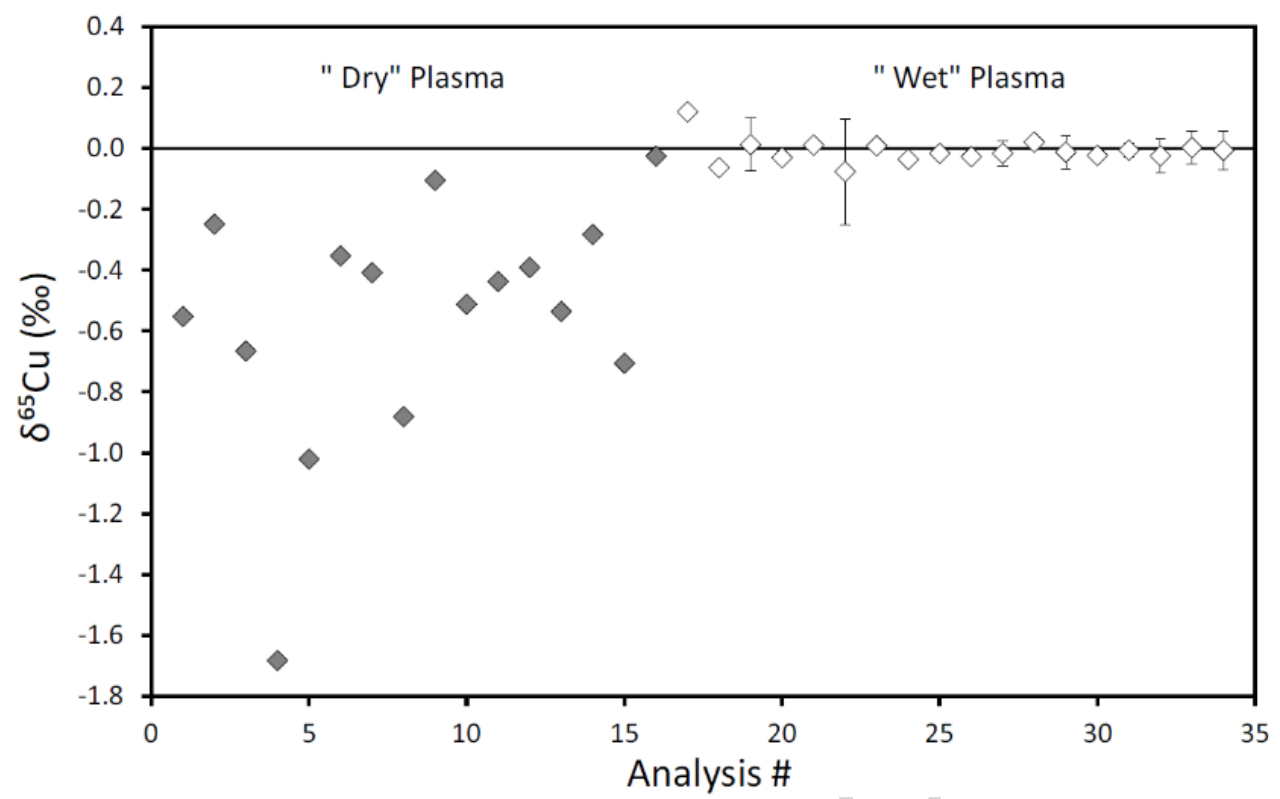

Figure 3: Corrected data on ultra-pure water enriched in standard Cu SRM976 after chemistry. Two types of introduction systems were used for the analysis: a desolvating nebulizer Apex-Q (grey diamonds) and a cyclonic spray chamber (white diamonds). Most of the samples were analyzed once. The samples analyzed several times are reported with an

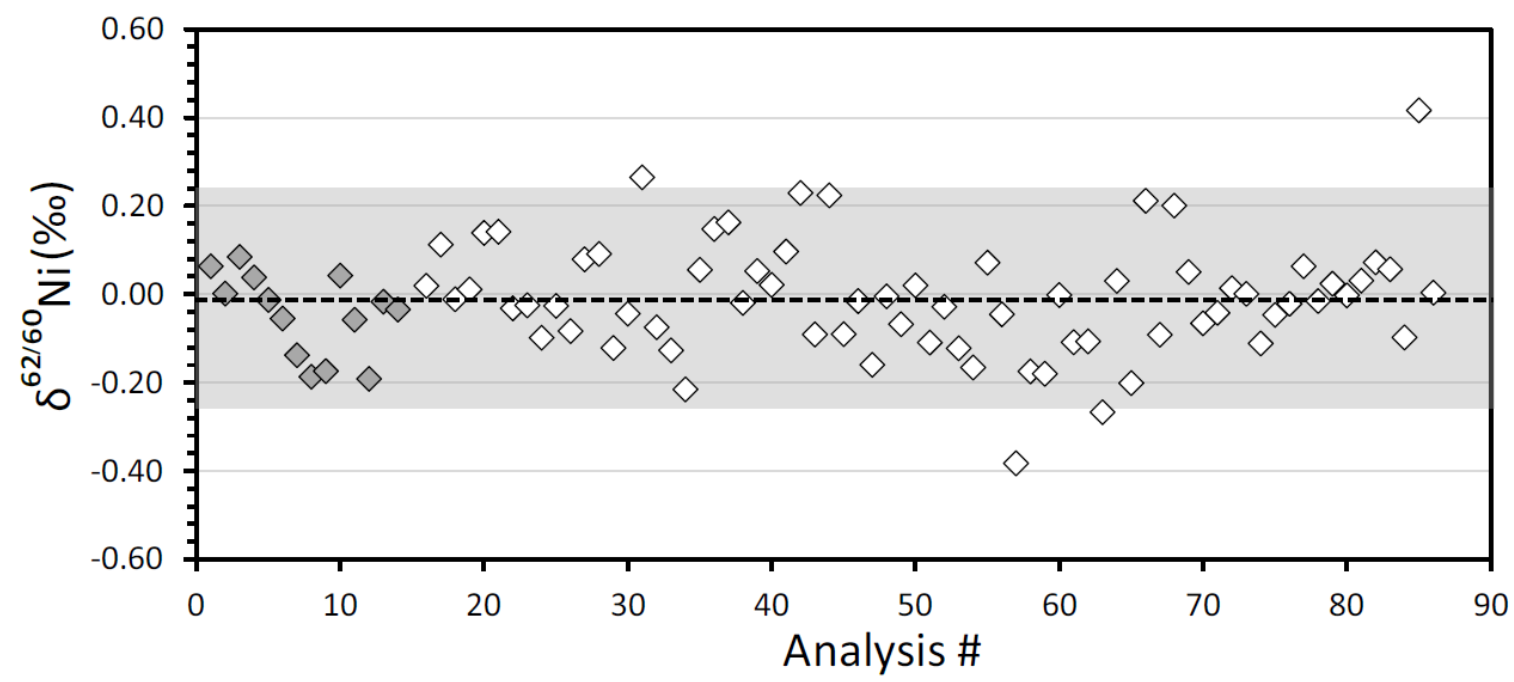

error bar at 2 s.d.

Figure 4: $\delta^{62 / 60} \mathrm{Ni}$ data on ultra-pure water enriched in standard Cu SRM976 (5 to $15 \mathrm{ng} \mathrm{ml}^{-1}$ ) and Ni SRM3136 (50 to $100 \mathrm{ng} \mathrm{ml}^{-1}$ ) after chemistry (grey diamonds), and standard solution of $\mathrm{Cu}$ SRM976 (10 to $20 \mathrm{ng} \mathrm{ml}^{-1}$ ) and Ni SRM3136 (50 to $100 \mathrm{ng} \mathrm{ml}^{-1}$ ) used as intercalibrating standards during the analysis (white diamonds). The average $\delta^{62 / 60} \mathrm{Ni}$ value for both standards and spiked blanks is $-0.01 \pm 0.25 \%$ (2s.d.; $\mathrm{n}=85)$. Both desolvating nebulizer Apex-Q and cyclonic spray chambers were used as introduction system and the analysis was done at medium resolution. 


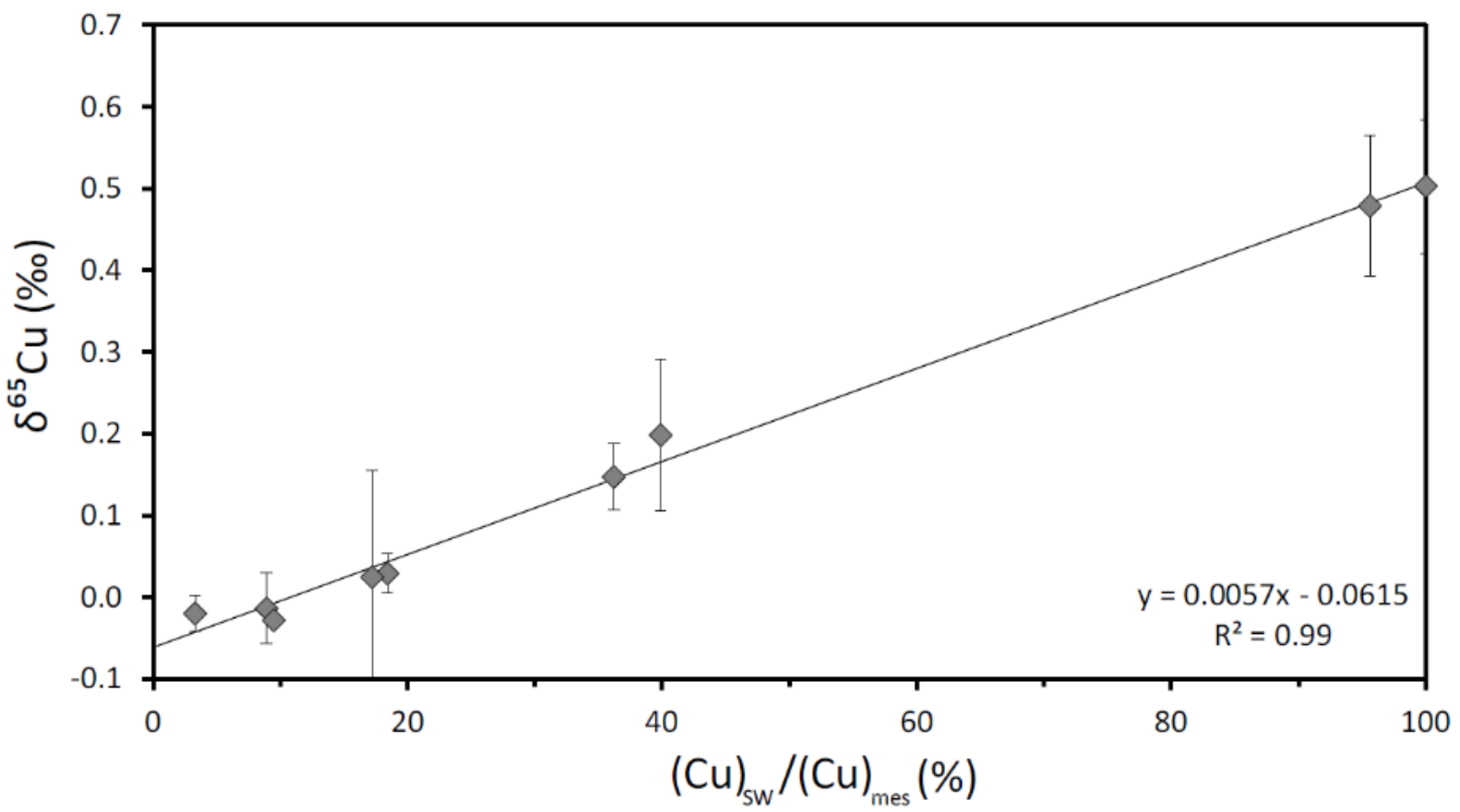

Figure 5: $\delta^{65} \mathrm{Cu}$ measured for a bulk of seawater over the ratio natural $\mathrm{Cu} /$ standard $\mathrm{Cu}$ SRM3114 added at various amount. 
Figure 6: Depth profiles of $[\mathrm{dCu}]_{\mathrm{T}}\left(\mathrm{nmol} \mathrm{kg}{ }^{-1}\right.$, white diamonds) and $\delta^{65} \mathrm{Cu}$ (\%o SRM976, grey diamonds) for all stations (besides station 1) in the Atlantic section, North and South Western Mediterranean Basin (NWMB and SWMB), North and south Eastern Mediterranean Basin (NEMB and SEMB), with approximate location of the water masses (see text for abbreviations), surface mixed layer (SML) and the depth of the Chl $a$ max

\section{Atlantic}

$\delta^{65} \mathrm{Cu}(\%$ o SRM976)

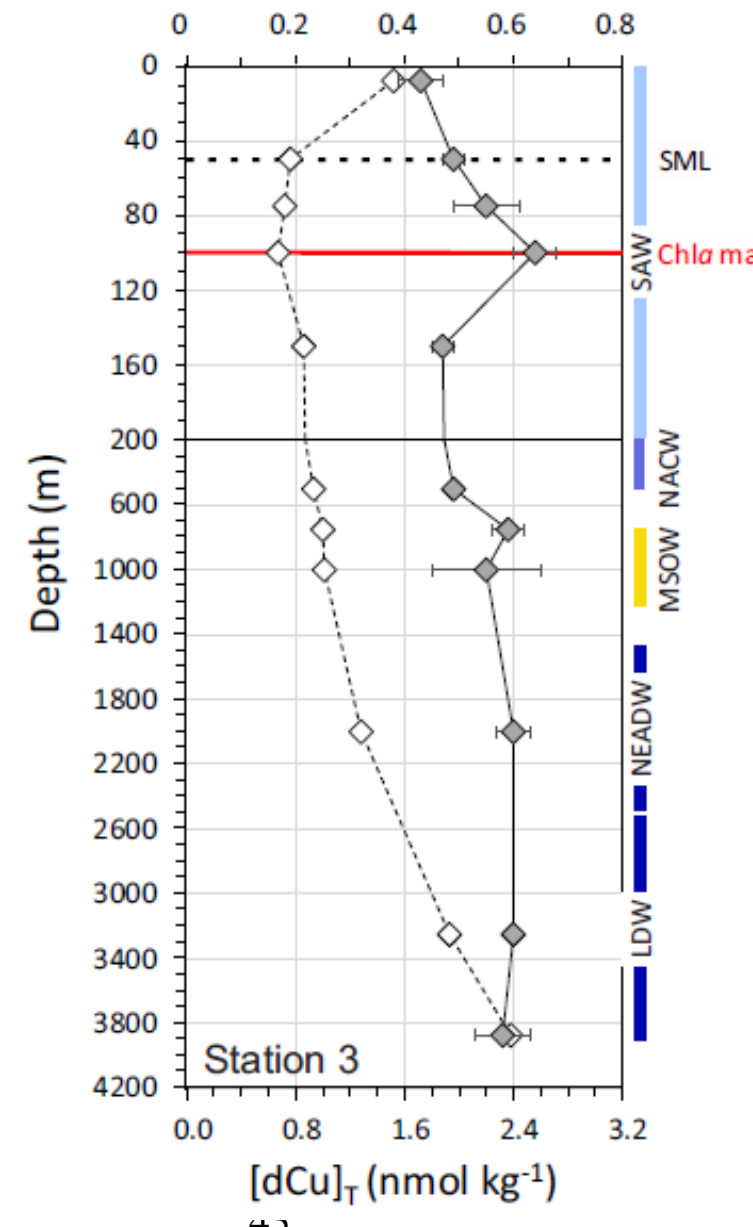

$\delta^{65} \mathrm{Cu}(\%$ SRM976)

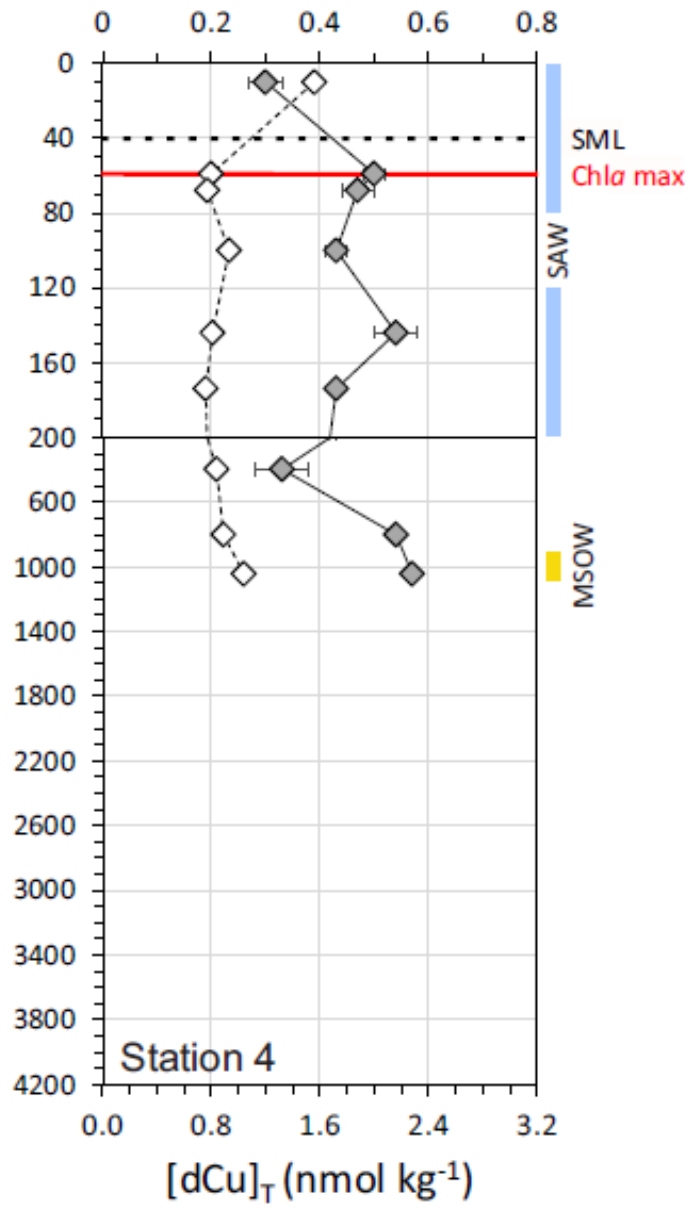

\section{SWMB}

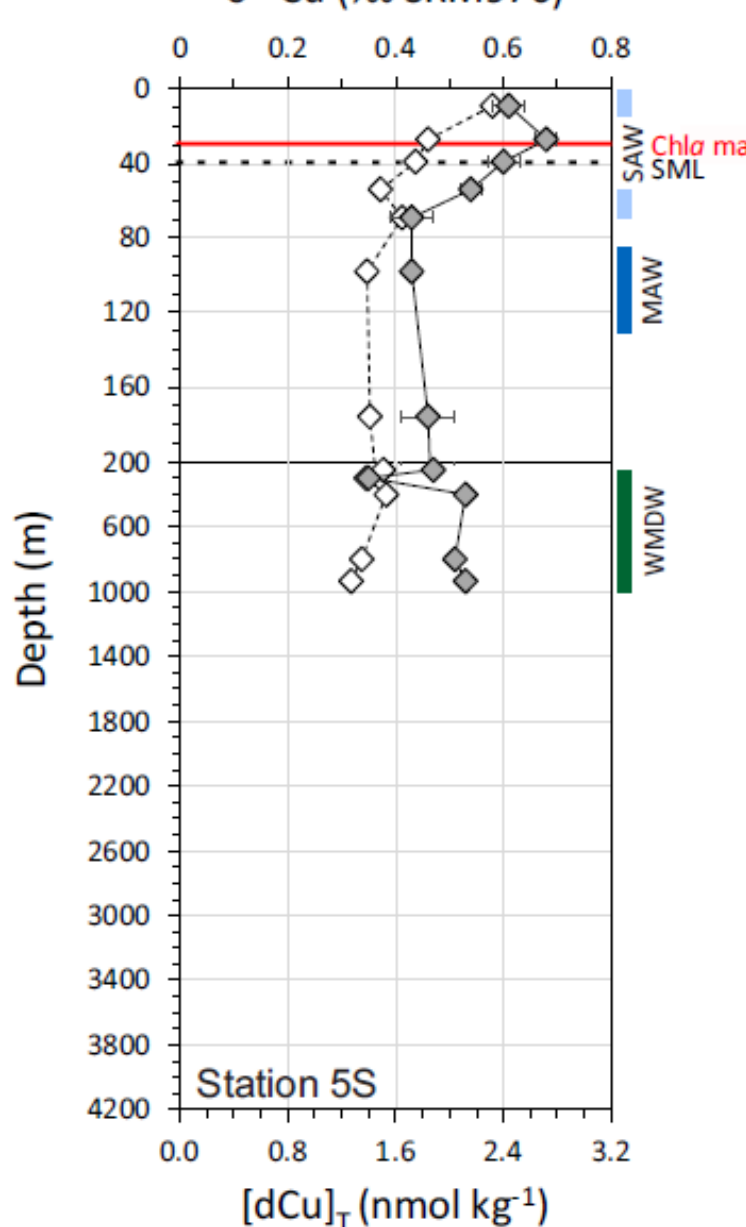

\section{$\delta^{65} \mathrm{Cu}(\%$ SRM976)}

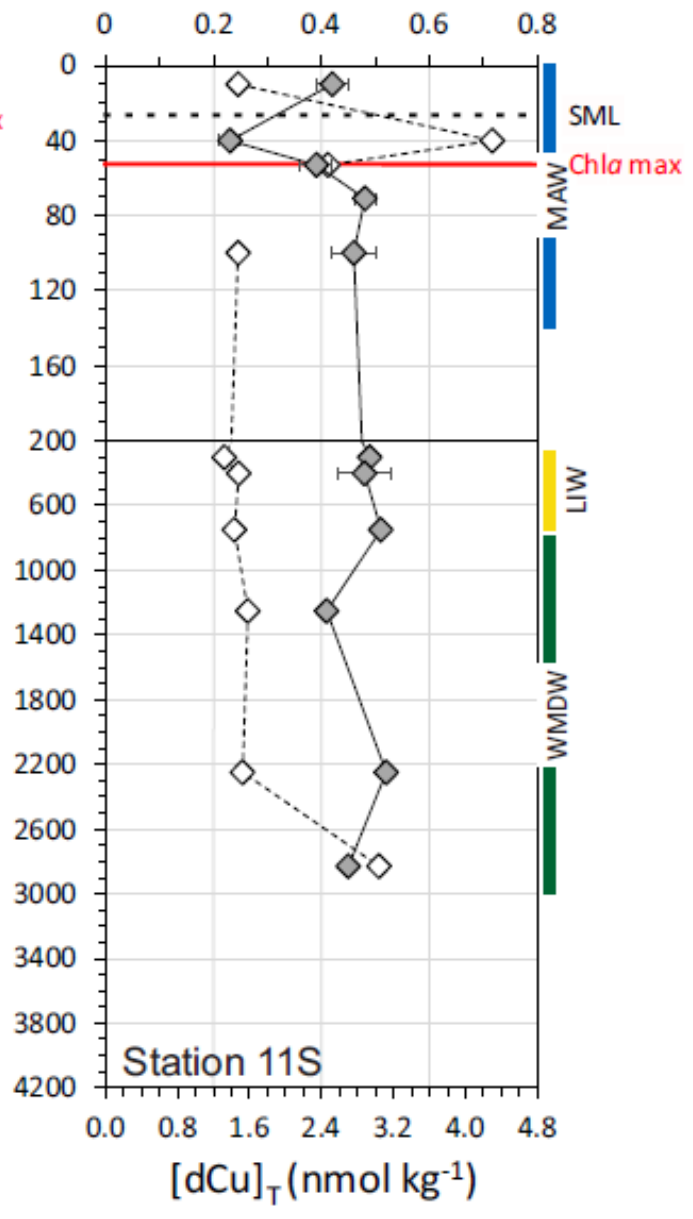


Figure 6: continued.

\section{SEMB}

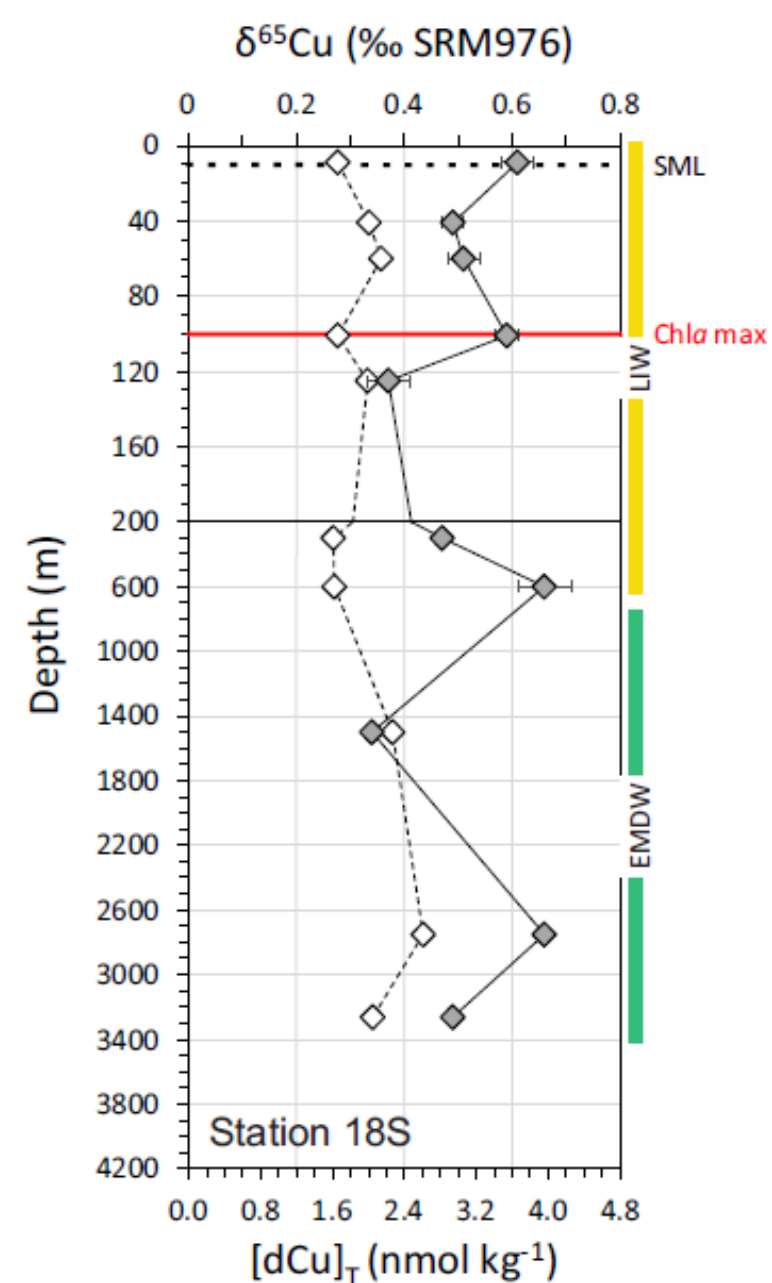

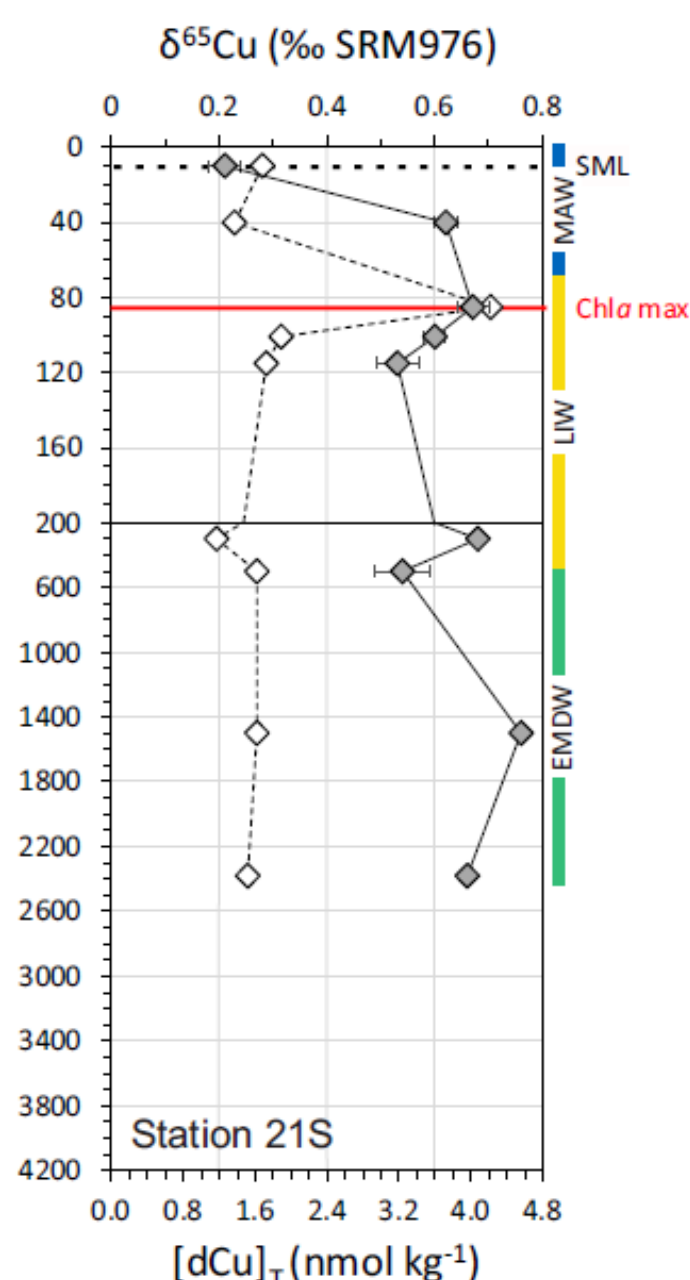

\section{NEMB}

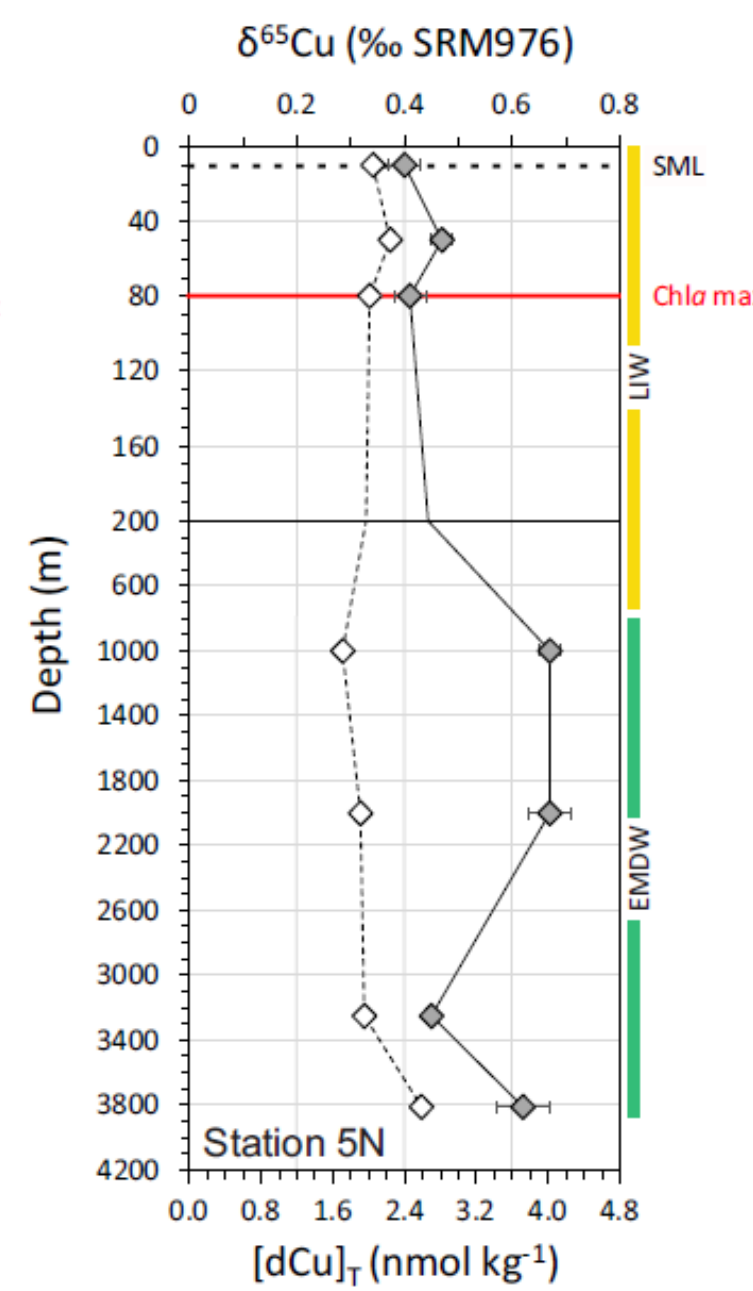

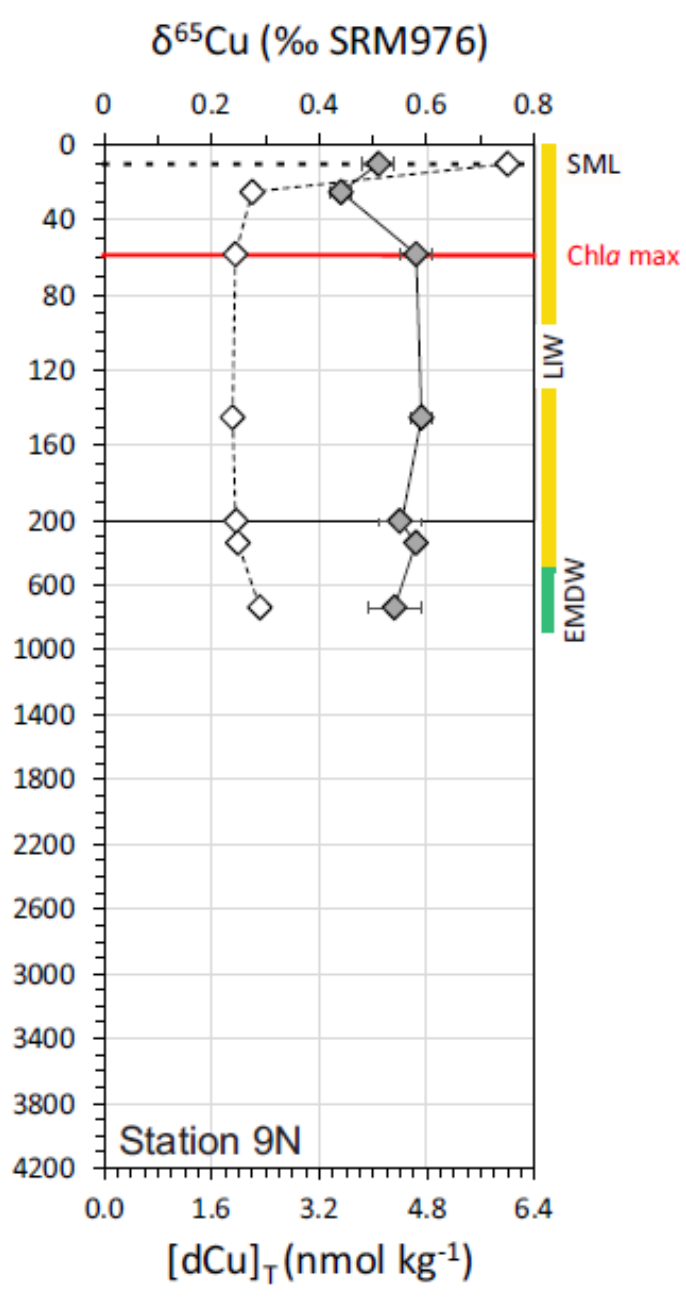


Figure 6: continued.

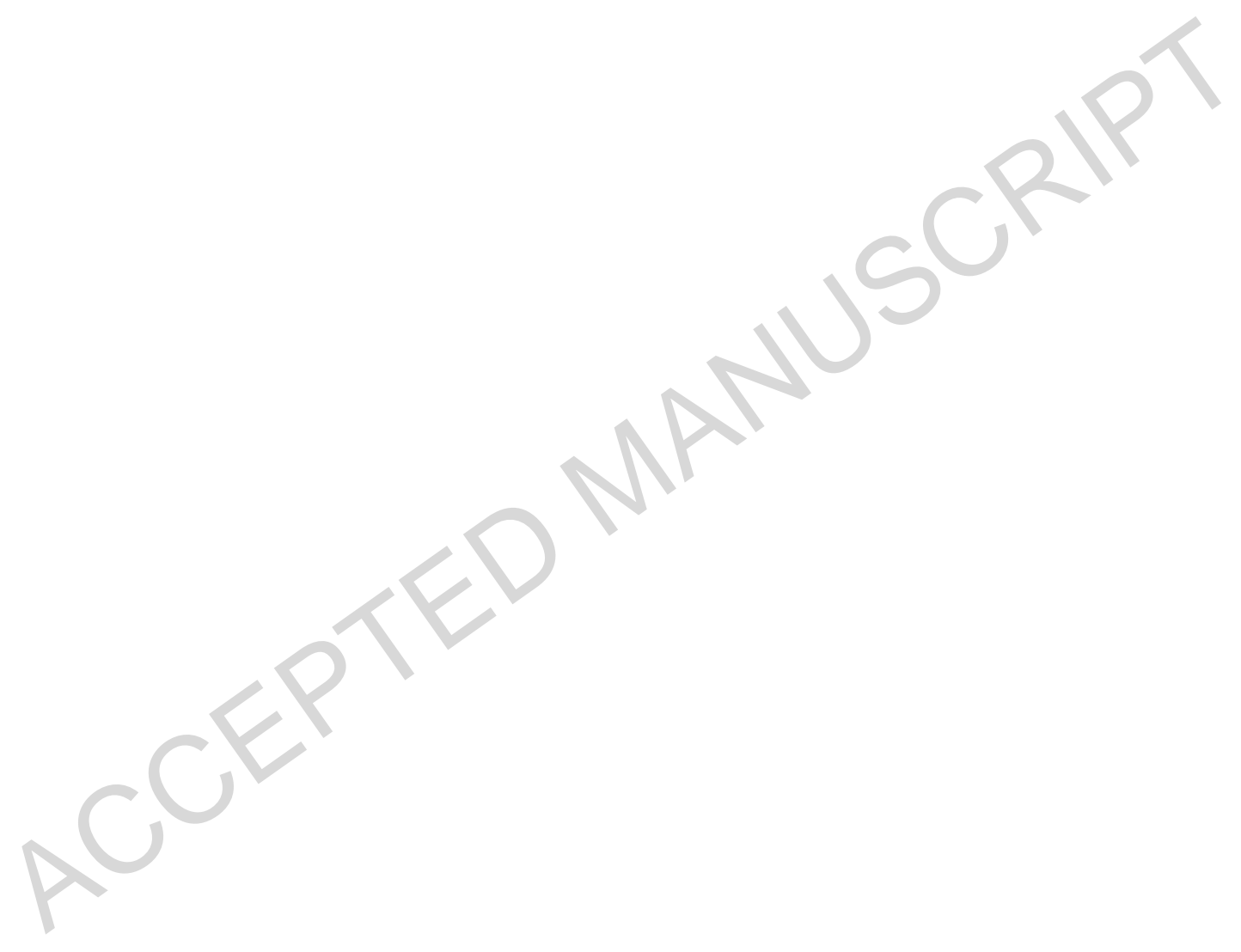




\section{NWMB}
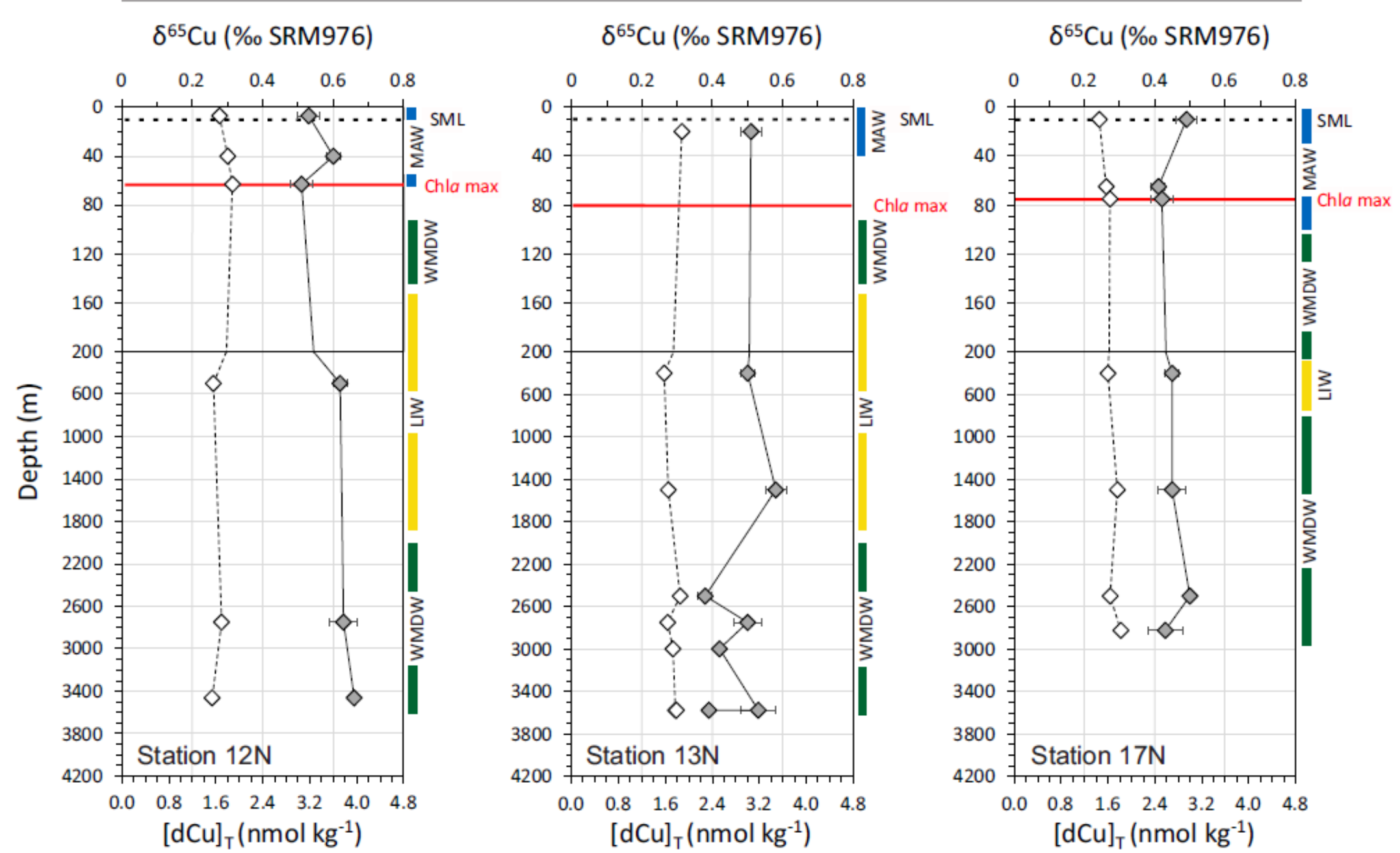


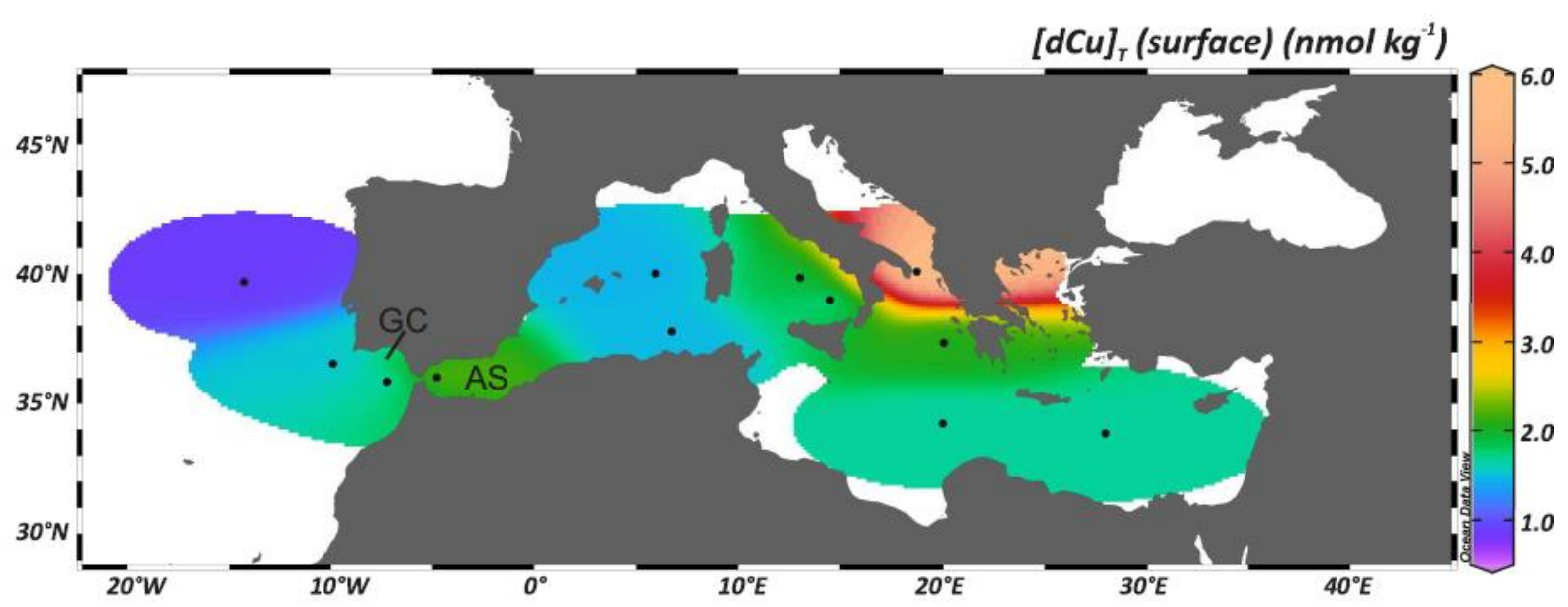

Figure 7: Isosurface variation of $[\mathrm{dCu}]_{\mathrm{T}}$ at $\sim 10 \mathrm{~m}$. Abbreviations shown in the map stand for: $\mathrm{AS}=$ Alboran Sea; GC = Gulf of Cadiz. Apart for station 5S in the Alboran Sea (case discussed in section 5.2.1), the Mediterranean stations show a South-West to North-East increase in concentration.

\section{Tables and Table captions}

Table 1: Procedure for dissolved $\mathrm{Cu}$ isotope analysis in a seawater sample.

Pre-treatment of the seawater samples:

Filtration: $0.2 \mu \mathrm{m}$

Acidification: $\mathrm{HCl}$ to $\mathrm{pH} \sim 1.7$

Addition of $\mathrm{H}_{2} \mathrm{O}_{2}: 0.03 \mathrm{wt} \%$

Chromatographic separation of $\mathrm{Cu}$ :

(1) NTA resin (1 mL, wet volume)

$\begin{array}{ll}\text { conditioning } & 25 \mathrm{~mL} \text { of } 0.02 \mathrm{M} \mathrm{HCl} \\ \text { sample loading } & 0.5 \mathrm{~L} \text { to } 1 \mathrm{~L} \text { pre-weighed } \\ \text { elution of major and trace elements } & 20 \mathrm{~mL} \text { of } 0.02 \mathrm{M} \mathrm{HCl}\end{array}$

*peristaltic pump OFF*

elution of $\mathrm{Cu}$

$10 \mathrm{~mL}$ of $1.4 \mathrm{M} \mathrm{HNO}_{3}(*)$

column cleaning

$10 \mathrm{~mL} 1.4 \mathrm{M} \mathrm{HNO}_{3}$

(2) AG MP-1M (1 ml, wet volume)

conditioning

sample loading

elution of major and trace elements

elution of $\mathrm{Cu}$

column cleaning
$3 \mathrm{~mL} 18.2 \mathrm{M} \Omega$ water

$2 \mathrm{~mL}$ of $10 \mathrm{M} \mathrm{HCl}$

$0.5 \mathrm{~mL}$ of $10 \mathrm{M} \mathrm{HCl}$

$3.5 \mathrm{~mL}$ of $10 \mathrm{~m} \mathrm{HCl}$

$12 \mathrm{~mL}$ of $5 \mathrm{M} \mathrm{HCl}$

$10 \mathrm{~mL} 3 \mathrm{M} \mathrm{HNO}_{3}$

$10 \mathrm{~mL} 18.2 \mathrm{M} \Omega$ water

$10 \mathrm{~mL} 1.2 \mathrm{M} \mathrm{HCl}$

(3) Sample evaporated on hot-plate and re-dissolved in concentrated $\mathrm{HNO}_{3}\left(\right.$ Optima ${ }^{\mathrm{TM}}$-Grade)

(4) Sample evaporated and re-dissolved in $0.28 \mathrm{M} \mathrm{HNO}_{3}$ for MC ICP-MS analysis

(*) Measurement of dissolved $\mathrm{Cu}$ concentration:

$0.4 \mathrm{~mL}$ of sample into $2 \mathrm{~mL}$ of $18.2 \mathrm{M} \Omega$ water for MC ICP-MS analysis

Table 2: $[\mathrm{dCu}]_{\mathrm{T}}\left(\mathrm{nmol} \mathrm{kg}{ }^{-1}\right)$ and $\delta^{65} \mathrm{Cu}(\%)$ for the Geotraces inter-comparison exercise, using BATS seawater sampled in 2008. The consensus values for the North Atlantic reference samples are available at es.ucsc.edu (concentrations only). The errors reported on these values were adapted to be at 2 s.d. When no duplicate was done, the concentration $[\mathrm{dCu}]_{\mathrm{T}}$ is reported at $5 \%$ RSD $(96 \%$ confidence $)$. 


\begin{tabular}{|c|c|c|c|c|c|c|c|}
\hline Station & $\begin{array}{c}\text { \#ID/Depth } \\
\text { (m) }\end{array}$ & $\begin{array}{c}{[\mathrm{dCu}]_{\mathrm{T}}} \\
\left(\mathrm{nmol} \mathrm{kg}{ }^{-1}\right)\end{array}$ & $\begin{array}{c}2 s . d . \\
\left(\mathrm{nmol} \mathrm{kg}^{-1}\right)\end{array}$ & $\mathrm{N}$ & $\begin{array}{c}\delta^{65} \mathrm{Cu} \\
(\%)\end{array}$ & $\begin{array}{l}2 s . d . \\
(\% o)\end{array}$ & $\mathrm{N}$ \\
\hline \multicolumn{8}{|c|}{ Consensus values (2011): no UV before pre-concentration } \\
\hline BATS & GS & 0.83 & 0.16 & & & & \\
\hline BATS & GD & 1.55 & 0.26 & & & & \\
\hline \multicolumn{8}{|c|}{ Boyle et al. (2012) : no UV before pre-concentration } \\
\hline BATS & GS & $0.74-0.89$ & & & $0.56-0.63$ & 0.09 & \\
\hline BATS & GD & $1.16-1.22$ & & & $0.56-0.57$ & 0.09 & \\
\hline \multicolumn{8}{|c|}{ Takano et al. (2014) : no UV before pre-concentration } \\
\hline BATS & GD & & & & 0.41 & 0.05 & \\
\hline \multicolumn{8}{|c|}{ Consensus values (2013) : use of UV before pre-concentration } \\
\hline BATS & GS & 0.84 & 0.12 & & & & \\
\hline BATS & GD & 1.62 & 0.14 & & & & \\
\hline \multicolumn{8}{|c|}{ This study : no UV before pre-concentration } \\
\hline BATS & GSI-72 & 0.81 & 0.06 & 2 & 0.42 & 0.06 & 3 \\
\hline BATS & GDI-74 & 1.38 & 0.13 & 2 & 0.62 & 0.06 & 3 \\
\hline 1 (Atlantic) & 23 & 0.89 & 0.16 & 3 & 0.41 & 0.06 & 9 \\
\hline 1 (Atlantic) & 1500 & 1.38 & & 1 & 0.60 & 0.08 & 5 \\
\hline
\end{tabular}


Table 3: Total dissolved $\mathrm{Cu}$ concentration $\left([\mathrm{dCu}]_{\mathrm{T}}\right)$ and $\delta^{65} \mathrm{Cu}$ for the Atlantic stations, the southern and northern Mediterranean Sea stations, along with absolute salinity $\left(\mathrm{S}_{\mathrm{A}}\right)$, conservative temperature (CT), density anomaly $\left(\sigma_{\theta}\right)$, chlorophyll a concentration $(\mathrm{Chl}$ a) and dissolved oxygen concentration modified from ship-board data. When no duplicate was done, the concentration $[\mathrm{dCu}]_{\mathrm{T}}$ is reported at $5 \% \mathrm{RSD}$ at $96 \%$ confidence level.

\begin{tabular}{|c|c|c|c|c|c|c|c|c|c|c|c|}
\hline $\begin{array}{c}\text { Depth } \\
\text { (m) }\end{array}$ & $\begin{array}{c}\mathrm{S}_{\mathrm{A}} \\
\left(\mathrm{g} \mathrm{kg}^{-1}\right)\end{array}$ & $\begin{array}{l}\mathrm{CT} \\
\left({ }^{\circ} \mathrm{C}\right) \\
\end{array}$ & $\begin{array}{c}\sigma_{\theta} \\
\left(\mathrm{kg} \mathrm{m}^{-3}\right)\end{array}$ & $\begin{array}{c}\text { Oxygen } \\
\left(\mu \mathrm{mol} \mathrm{kg}{ }^{-1}\right)\end{array}$ & $\begin{array}{c}\text { Chl a } \\
\left(\mathrm{mg} \mathrm{m}^{-3}\right)\end{array}$ & $\begin{array}{c}{[\mathrm{dCu}]_{\mathrm{T}}} \\
\left(\mathrm{nmol} \mathrm{kg}^{-1}\right)\end{array}$ & $\begin{array}{c}\text { 2s.d. } \\
\left(\mathrm{nmol} \mathrm{kg}^{-1}\right)\end{array}$ & $\mathrm{N}$ & $\begin{array}{c}\delta^{65} \mathrm{Cu} \\
(\% 0)\end{array}$ & $\begin{array}{l}\text { 2s.d. } \\
(\%)\end{array}$ & $\mathrm{N}$ \\
\hline \multicolumn{12}{|c|}{ Station $1\left(39.733^{\circ} \mathrm{N}-14.167^{\circ} \mathrm{W} ; 5265 \mathrm{~m}\right)$} \\
\hline 23 & 36.18 & 15.0 & 26.75 & 254.0 & 0.80 & 0.89 & 0.16 & 3 & 0.41 & 0.06 & 9 \\
\hline 1499 & 35.80 & 7.4 & 27.85 & 214.0 & 0.00 & 1.38 & & & 0.60 & 0.08 & 5 \\
\hline \multicolumn{12}{|c|}{ Station $3\left(36.566^{\circ} \mathrm{N}-9.866^{\circ} \mathrm{W} ; 3940 \mathrm{~m}\right)$} \\
\hline 8 & 36.67 & 17.7 & 26.49 & 238.3 & 0.05 & 1.52 & & 2 & 0.43 & 0.06 & 3 \\
\hline 50 & 36.67 & 17.7 & 26.49 & 238.0 & 0.04 & 0.76 & & 1 & 0.49 & 0.06 & 3 \\
\hline 75 & 36.65 & 17.4 & 26.54 & 240.5 & 0.07 & 0.72 & & 1 & 0.55 & 0.06 & 3 \\
\hline 100 & 36.53 & 16.4 & 26.69 & 232.1 & 0.25 & 0.67 & & 1 & 0.64 & 0.06 & 3 \\
\hline 151 & 36.37 & 15.3 & 26.81 & 214.9 & 0.02 & 0.86 & & 1 & 0.47 & 0.06 & 3 \\
\hline 503 & 35.80 & 11.5 & 27.17 & 191.2 & 0.00 & 0.93 & & 1 & 0.49 & 0.06 & 2 \\
\hline 752 & 35.97 & 10.7 & 27.46 & 174.7 & 0.02 & 1.00 & & 1 & 0.59 & 0.06 & 3 \\
\hline 1001 & 36.11 & 10.1 & 27.67 & 177.8 & 0.00 & 1.01 & & 1 & 0.55 & 0.10 & 3 \\
\hline 2000 & 35.35 & 4.4 & 27.88 & 236.3 & 0.00 & 1.28 & & 1 & 0.60 & 0.06 & 3 \\
\hline 3251 & 35.10 & 2.4 & 27.88 & 240.5 & 0.00 & 1.93 & & 1 & 0.60 & 0.06 & 3 \\
\hline 3875 & 35.07 & 2.1 & 27.89 & 236.7 & 0.00 & 2.38 & & 1 & 0.58 & 0.06 & 3 \\
\hline \multicolumn{12}{|c|}{ Station $4\left(35.842^{\circ} \mathrm{N}-7.256^{\circ} \mathrm{W} ; 1053 \mathrm{~m}\right)$} \\
\hline 10 & 36.62 & 18.0 & 26.38 & 234.8 & 0.05 & 1.56 & & 1 & 0.30 & 0.06 & 4 \\
\hline 59 & 36.59 & 16.5 & 26.71 & 244.1 & 0.44 & 0.80 & & 1 & 0.50 & 0.08 & 3 \\
\hline 68 & 36.59 & 16.3 & 26.76 & 234.8 & 0.22 & 0.77 & & 1 & 0.47 & 0.06 & 3 \\
\hline 100 & 36.58 & 16.1 & 26.81 & 226.6 & 0.05 & 0.93 & & 1 & 0.43 & 0.08 & 3 \\
\hline 144 & 36.53 & 15.7 & 26.84 & 222.7 & 0.01 & 0.81 & & 1 & 0.54 & 0.06 & 2 \\
\hline 174 & 36.49 & 15.6 & 26.86 & 222.1 & 0.01 & 0.76 & & 1 & 0.43 & 0.06 & 2 \\
\hline 398 & 35.99 & 12.9 & 27.03 & 202.8 & 0.00 & 0.84 & & 1 & 0.33 & 0.06 & 3 \\
\hline 801 & 35.89 & 10.3 & 27.46 & 167.1 & 0.00 & 0.89 & & 1 & 0.54 & 0.06 & 2 \\
\hline 1043 & 37.00 & 12.2 & 27.97 & 178.0 & 0.00 & 1.04 & & 1 & 0.57 & 0.06 & 3 \\
\hline \multicolumn{12}{|c|}{ Station $5 S\left(36.058^{\circ} \mathrm{N}-4.814^{\circ} \mathrm{W} ; 943 \mathrm{~m}\right)$} \\
\hline 9 & 36.44 & 17.0 & 26.49 & 244.0 & 0.11 & 2.32 & 0.04 & 2 & 0.61 & 0.06 & 4 \\
\hline 27 & 36.46 & 16.9 & 26.53 & 243.7 & 0.34 & 1.84 & & 1 & 0.68 & 0.08 & 4 \\
\hline 39 & 36.51 & 16.8 & 26.58 & 236.7 & 0.37 & 1.75 & & 1 & 0.60 & 0.08 & 4 \\
\hline 54 & 36.56 & 16.6 & 26.65 & 232.9 & 0.38 & 1.49 & & 1 & 0.54 & 0.07 & 4 \\
\hline 69 & 36.81 & 15.9 & 27.01 & 229.0 & 0.21 & 1.65 & 0.11 & 2 & 0.43 & 0.18 & 3 \\
\hline 98 & 37.54 & 14.5 & 27.90 & 214.0 & 0.02 & 1.39 & & 1 & 0.43 & 0.06 & 3 \\
\hline 176 & 38.58 & 13.1 & 28.99 & 165.3 & 0.02 & 1.41 & & 1 & 0.46 & 0.06 & 4 \\
\hline 249 & 38.68 & 13.1 & 29.07 & 162.0 & 0.00 & 1.51 & 0.02 & 2 & 0.47 & 0.16 & 4 \\
\hline 299 & 38.70 & 13.1 & 29.08 & 163.2 & 0.01 & 1.38 & & 1 & 0.35 & 0.06 & 4 \\
\hline 400 & 38.70 & 13.0 & 29.09 & 173.5 & 0.02 & 1.53 & 0.03 & 2 & 0.53 & 0.06 & 3 \\
\hline 800 & 38.67 & 12.9 & 29.10 & & 0.00 & 1.35 & & 1 & 0.51 & 0.06 & 3 \\
\hline 934 & 38.66 & 12.8 & 29.11 & & 0.00 & 1.27 & & 1 & 0.53 & 0.07 & 4 \\
\hline
\end{tabular}




\begin{tabular}{|c|c|c|c|c|c|c|c|c|c|c|c|}
\hline $\begin{array}{l}\text { Depth } \\
(\mathrm{m})\end{array}$ & $\begin{array}{c}\mathrm{SA} \\
\left(\mathrm{g} \mathrm{kg}^{-1}\right)\end{array}$ & $\begin{array}{l}\mathrm{CT} \\
\left({ }^{\circ} \mathrm{C}\right) \\
\end{array}$ & $\begin{array}{c}\sigma_{\theta} \\
\left(\mathrm{kg} \mathrm{m}^{-3}\right) \\
\end{array}$ & $\begin{array}{c}\text { Oxygen } \\
\left.(\mu \mathrm{mol} \mathrm{kg})^{-1}\right)\end{array}$ & $\begin{array}{c}\text { Chl a } \\
\left(\mathrm{mg} \mathrm{m}^{-3}\right)\end{array}$ & $\begin{array}{c}{[\mathrm{dCu}]_{\mathrm{T}}} \\
\left(\mathrm{nmol} \mathrm{kg}^{-1}\right) \\
\end{array}$ & $\begin{array}{c}2 s . d . \\
\left(\text { nmol kg }^{-1}\right)\end{array}$ & $\mathrm{N}$ & $\begin{array}{c}\delta^{65} \mathrm{Cu} \\
(\%) \\
\end{array}$ & $\begin{array}{l}2 s . d . \\
(\%)\end{array}$ & $\mathrm{N}$ \\
\hline \multicolumn{12}{|c|}{ Station $11 S\left(37.778^{\circ} \mathrm{N}-6.663^{\circ} \mathrm{E} ; 2871 \mathrm{~m}\right)$} \\
\hline 10 & 37.28 & 17.4 & 27.03 & 222.8 & 0.10 & 1.47 & 0.18 & 2 & 0.42 & 0.06 & 5 \\
\hline 40 & 37.28 & 15.1 & 27.65 & 231.3 & 0.30 & 4.30 & 0.12 & 2 & 0.23 & 0.06 & 3 \\
\hline 53 & 37.44 & 14.7 & 27.78 & 226.7 & 0.62 & 2.47 & 0.06 & 2 & 0.39 & 0.06 & 3 \\
\hline 71 & 37.64 & 14.5 & 27.97 & 216.3 & 0.07 & & & & 0.48 & 0.06 & 2 \\
\hline 100 & 37.99 & 14.0 & 28.35 & 207.3 & 0.02 & 1.47 & & 1 & 0.46 & 0.06 & 4 \\
\hline 303 & 38.74 & 13.4 & 29.05 & 157.3 & 0.00 & 1.32 & & 1 & 0.49 & 0.06 & 1 \\
\hline 400 & 38.77 & 13.3 & 29.08 & 160.7 & 0.01 & 1.48 & & 1 & 0.48 & 0.06 & 3 \\
\hline 751 & 38.74 & 13.1 & 29.10 & 165.9 & 0.01 & 1.43 & & 1 & 0.51 & 0.06 & 3 \\
\hline 1252 & 38.66 & 12.8 & 29.11 & 174.7 & 0.00 & 1.58 & & 1 & 0.41 & 0.06 & 3 \\
\hline 2250 & 38.66 & 12.8 & 29.11 & 182.0 & 0.01 & 1.52 & & 1 & 0.52 & 0.06 & 4 \\
\hline 2830 & 38.67 & 12.8 & 29.12 & 183.7 & 0.01 & 3.04 & & 2 & 0.45 & 0.06 & 3 \\
\hline \multicolumn{12}{|c|}{ Station $18 S\left(34.284^{\circ} \mathrm{N}-20.016^{\circ} \mathrm{E} ; 3263 \mathrm{~m}\right)$} \\
\hline 9 & 39.22 & 20.5 & 27.67 & 231.9 & 0.02 & 1.66 & 0.09 & 2 & 0.61 & 0.19 & 6 \\
\hline 41 & 39.22 & 17.5 & 28.47 & 255.0 & 0.04 & 2.01 & 0.01 & 2 & 0.49 & 0.07 & 3 \\
\hline 60 & 39.20 & 16.3 & 28.74 & 250.7 & 0.05 & 2.14 & 0.01 & 2 & 0.51 & 0.06 & 3 \\
\hline 101 & 39.20 & 15.4 & 28.94 & 223.5 & 0.10 & 1.66 & & 1 & 0.59 & 0.06 & 2 \\
\hline 125 & 39.19 & 15.2 & 28.99 & 212.8 & 0.09 & 1.99 & & 1 & 0.37 & 0.06 & 2 \\
\hline 300 & 39.12 & 14.4 & 29.13 & 197.7 & 0.00 & 1.61 & & 1 & 0.47 & 0.13 & 2 \\
\hline 600 & 39.02 & 13.9 & 29.16 & 191.3 & 0.02 & 1.62 & 0.05 & 2 & 0.66 & 0.06 & 3 \\
\hline 1499 & 38.93 & 13.4 & 29.19 & 198.9 & 0.00 & 2.27 & 0.15 & 2 & 0.34 & 0.06 & 3 \\
\hline 2750 & 38.91 & 13.3 & 29.20 & 205.2 & 0.01 & 2.61 & 0.79 & 2 & 0.66 & 0.06 & 3 \\
\hline 3263 & 39.02 & 13.3 & 29.28 & 200.8 & 0.02 & 2.05 & 0.12 & 2 & 0.49 & 0.06 & 2 \\
\hline \multicolumn{12}{|c|}{ Station $21 S\left(33.843^{\circ} \mathrm{N}-28.082^{\circ} \mathrm{E} ; 2673 \mathrm{~m}\right)$} \\
\hline 10 & 38.97 & 21.6 & 27.18 & 227.8 & 0.04 & 1.68 & 0.15 & 2 & 0.21 & 0.06 & 5 \\
\hline 40 & 38.85 & 17.5 & 28.19 & 250.2 & 0.04 & 1.37 & 0.01 & 2 & 0.62 & 0.06 & 3 \\
\hline 85 & 39.06 & 16.4 & 28.61 & 236.5 & 0.09 & 4.22 & 0.13 & 2 & 0.67 & 0.06 & 3 \\
\hline 101 & 39.17 & 16.5 & 28.68 & 236.0 & 0.06 & 1.89 & 0.03 & 2 & 0.60 & 0.06 & 4 \\
\hline 115 & 39.18 & 16.2 & 28.76 & 232.8 & 0.05 & 1.72 & & 1 & 0.53 & 0.11 & 2 \\
\hline 301 & 39.18 & 14.7 & 29.11 & 212.3 & 0.00 & 1.17 & 0.04 & 2 & 0.68 & 0.06 & 3 \\
\hline 501 & 39.02 & 13.9 & 29.16 & 189.7 & 0.02 & 1.62 & 0.33 & 2 & 0.54 & 0.06 & 3 \\
\hline 1500 & 38.94 & 13.5 & 29.18 & 193.1 & 0.01 & 1.62 & 0.01 & 2 & 0.76 & 0.06 & 3 \\
\hline 2380 & 38.96 & 13.5 & 29.20 & 198.5 & 0.02 & 1.52 & & 1 & 0.66 & 0.06 & 3 \\
\hline \multicolumn{12}{|c|}{ Station $5 N\left(37.378^{\circ} N-20.164^{\circ} \mathrm{E} ; 3875 \mathrm{~m}\right)$} \\
\hline 10 & 39.32 & 25.5 & 26.25 & 203.0 & 0.03 & 2.05 & & 1 & 0.40 & 0.06 & 3 \\
\hline 50 & 39.00 & 16.6 & 28.53 & 267.3 & 0.06 & 2.24 & & 1 & 0.47 & 0.06 & 3 \\
\hline 80 & 39.04 & 15.2 & 28.89 & 233.3 & 0.26 & 2.01 & & 1 & 0.41 & 0.07 & 3 \\
\hline 1000 & 38.96 & 13.6 & 29.18 & 179.1 & 0.02 & 1.71 & & 1 & 0.67 & 0.19 & 4 \\
\hline 2000 & 38.93 & 13.4 & 29.19 & 186.0 & 0.02 & 1.91 & & 1 & 0.67 & 0.06 & 3 \\
\hline 3250 & 38.91 & 13.3 & 29.20 & 188.2 & 0.01 & 1.95 & & 1 & 0.45 & 0.06 & 2 \\
\hline 3812 & 38.92 & 13.3 & 29.20 & 187.5 & 0.01 & 2.59 & & 1 & 0.62 & 0.06 & 3 \\
\hline
\end{tabular}




\begin{tabular}{|c|c|c|c|c|c|c|c|c|c|c|c|}
\hline Depth & SA & CT & $\sigma_{\theta}$ & Oxygen & Chl a & {$[\mathrm{dCu}]_{\mathrm{T}}$} & $2 s . d$. & $\mathrm{N}$ & $\delta^{65} \mathrm{Cu}$ & $2 s . d$. & $\mathrm{N}$ \\
\hline (m) & $\left(\mathrm{g} \mathrm{kg}^{-1}\right)$ & $\left({ }^{\circ} \mathrm{C}\right)$ & $\left(\mathrm{kg} \mathrm{m}^{-3}\right)$ & $\left(\mu \mathrm{mol} \mathrm{kg}{ }^{-1}\right)$ & $(\mathrm{mg} \mathrm{m}-3)$ & $\left(\mathrm{nmol} \mathrm{kg}^{-1}\right)$ & $($ nmol kg-1) & & $(\%)$ & (\%) & \\
\hline \multicolumn{12}{|c|}{ Station $9 N\left(40.154^{\circ} \mathrm{N}-18.817^{\circ} \mathrm{E} ; 739 \mathrm{~m}\right)$} \\
\hline 10 & 38.81 & 24.9 & 26.06 & 208.8 & 0.03 & 6.00 & 0.19 & 2 & 0.51 & 0.06 & 3 \\
\hline 25 & 39.08 & 17.0 & 28.47 & 248.5 & 0.04 & 2.20 & & 1 & 0.44 & 0.11 & 4 \\
\hline 58 & 39.04 & 15.1 & 28.91 & 236.3 & 0.28 & 1.95 & 0.06 & 2 & 0.58 & 0.06 & 3 \\
\hline 145 & 39.13 & 14.8 & 29.03 & 209.4 & 0.02 & 1.91 & 0.14 & 2 & 0.59 & 0.07 & 3 \\
\hline 205 & 39.14 & 14.7 & 29.06 & 206.3 & 0.02 & 1.96 & & 1 & 0.55 & 0.06 & 2 \\
\hline 340 & 39.07 & 14.2 & 29.11 & 206.5 & 0.02 & 1.99 & & 1 & 0.58 & 0.06 & 3 \\
\hline 739 & 38.94 & 13.4 & 29.21 & 213.9 & 0.02 & 2.32 & & & 0.54 & 0.11 & 3 \\
\hline \multicolumn{12}{|c|}{ Station $12 N\left(39.007^{\circ} \mathrm{N}-14.502^{\circ} \mathrm{E} ; 3464 \mathrm{~m}\right)$} \\
\hline 7 & 38.18 & 26.0 & 25.26 & 195.4 & 0.04 & 1.66 & 0.10 & 2 & 0.53 & 0.02 & 4 \\
\hline 40 & 37.98 & 15.6 & 27.97 & 255.1 & 0.06 & 1.80 & 0.16 & 2 & 0.60 & 0.12 & 5 \\
\hline 63 & 38.23 & 14.4 & 28.45 & 227.1 & 0.28 & 1.88 & 0.24 & 2 & 0.51 & 0.06 & 5 \\
\hline 500 & 38.95 & 14.0 & 29.08 & 176.9 & 0.02 & 1.56 & 0.08 & 2 & 0.62 & 0.15 & 4 \\
\hline 2749 & 38.69 & 12.9 & 29.11 & 178.7 & 0.02 & 1.70 & 0.18 & 2 & 0.63 & 0.11 & 5 \\
\hline 3464 & 38.68 & 12.9 & 29.11 & 176.3 & 0.01 & 1.54 & 0.00 & 2 & 0.66 & 0.09 & 6 \\
\hline \multicolumn{12}{|c|}{ Station $13 N\left(39.878^{\circ} \mathrm{N}-13.010^{\circ} \mathrm{E} ; 3576 \mathrm{~m}\right)$} \\
\hline 20 & 38.07 & 20.9 & 26.71 & 249.2 & 0.04 & 1.88 & & 1 & 0.51 & 0.06 & 3 \\
\hline 400 & 38.95 & 14.0 & 29.07 & 175.7 & 0.02 & 1.58 & & 1 & 0.50 & 0.07 & 3 \\
\hline 1500 & 38.74 & 13.1 & 29.11 & 178.4 & 0.02 & 1.65 & & 1 & 0.58 & 0.06 & 3 \\
\hline 2500 & 38.69 & 12.9 & 29.11 & 179.4 & 0.02 & 1.85 & & 1 & 0.38 & 0.06 & 2 \\
\hline 2750 & 38.69 & 12.9 & 29.11 & 180.4 & 0.02 & 1.64 & & 1 & 0.50 & 0.06 & 3 \\
\hline 2999 & 38.68 & 12.9 & 29.11 & 181.0 & 0.01 & 1.73 & & 1 & 0.42 & 0.06 & 3 \\
\hline 3576 & 38.68 & 12.9 & 29.11 & 181.0 & 0.01 & 1.77 & & 1 & 0.53 & 0.06 & 3 \\
\hline 3576 & 38.68 & 12.9 & 29.11 & 181.0 & 0.02 & 1.79 & 0.10 & 2 & 0.39 & 0.06 & 3 \\
\hline \multicolumn{12}{|c|}{ Station $17 N\left(40.069^{\circ} \mathrm{N}-5.947^{\circ} \mathrm{E} ; 2824 \mathrm{~m}\right)$} \\
\hline 10 & 37.89 & 26.6 & 24.87 & 206.4 & 0.04 & 1.45 & 0.11 & 2 & 0.49 & 0.06 & 2 \\
\hline 65 & 37.71 & 15.6 & 27.76 & 253.7 & 0.24 & 1.57 & 0.06 & 2 & 0.41 & 0.06 & 2 \\
\hline 75 & 37.80 & 15.0 & 27.97 & 237.0 & 0.67 & 1.63 & 0.02 & 2 & 0.42 & 0.06 & 3 \\
\hline 400 & 38.75 & 13.3 & 29.09 & 175.7 & 0.02 & 1.60 & & 1 & 0.45 & 0.06 & 2 \\
\hline 1500 & 38.66 & 12.8 & 29.11 & 190.3 & 0.02 & 1.76 & 0.04 & 2 & 0.45 & 0.06 & 3 \\
\hline 2499 & 38.67 & 12.8 & 29.12 & 194.0 & 0.02 & 1.64 & & 1 & 0.50 & 0.06 & 3 \\
\hline 2824 & 38.68 & 12.8 & 29.12 & 195.3 & 0.02 & 1.82 & & 1 & 0.43 & 0.06 & 3 \\
\hline
\end{tabular}

